\title{
Nutrient Status of San Francisco Bay and Its Management Implications
}

\author{
James E. Cloern ${ }^{1} \cdot$ Tara S. Schraga $^{1} \cdot$ Erica Nejad $^{1} \cdot$ Charles Martin $^{1}$ \\ Received: 4 June 2019 / Revised: 19 March 2020 / Accepted: 20 March 2020 / Published online: 15 April 2020 \\ (C) The Author(s) 2020
}

\begin{abstract}
Nutrient enrichment has degraded many of the world's estuaries by amplifying algal production, leading to hypoxia/anoxia, loss of vascular plants and fish/shellfish habitat, and expansion of harmful blooms (HABs). Policies to protect coastal waters from the effects of nutrient enrichment require information to determine if a water body is impaired by nutrients and if regulatory actions are required. We compiled information to inform these decisions for San Francisco Bay (SFB), an urban estuary where the best path toward nutrient management is not yet clear. Our results show that SFB has high nutrient loadings, primarily from municipal wastewater; there is potential for high algal production, but that production is not fully realized; and SFB is not impaired by hypoxia or recurrent HABs. However, our assessment includes reasons for concern: nitrogen and phosphorus concentrations higher than those in other estuaries impaired by nutrient pollution, chronic presences of multiple algal toxins, a recent increase of primary production, and projected future hydroclimatic conditions that could increase the magnitude and frequency of algal blooms. Policymakers thus face the challenge of determining the appropriate protective policy for SFB. We identify three crucial next steps for meeting this challenge: (1) new research to determine if algal toxins can be reduced through nutrient management, (2) establish management goals as numeric targets, and (3) determine the magnitude of nutrient load reduction required to meet those targets. Our case study illustrates how scientific information can be acquired and communicated to inform policymakers about the status of nutrient pollution, its risks, and strategies for minimizing those risks.
\end{abstract}

Keywords Estuary $\cdot$ Nutrients $\cdot$ Pollution $\cdot$ Eutrophication $\cdot$ Policy $\cdot$ Management $\cdot$ San Francisco Bay

\section{Introduction}

The world's estuaries, bays, and lagoons, and in particular those set in urban landscapes or agricultural watersheds, have been enriched in nitrogen and phosphorus by human activities. Nutrient pollution has been judged the largest pollution problem in US coastal rivers and bays (Howarth et al. 2002), and it is a growing problem of global scale. Nutrient enrichment alters coastal ecosystems through a suite of changes that begin with increased algal production and biomass, leading to increased ecosystem metabolism, turbidity, and occurrences of harmful algal blooms, and decreases of oxygen, vascular

Communicated by Mark J. Brush

James E. Cloern

jecloern@usgs.gov

1 US Geological Survey, 345 Middlefield Rd, Menlo Park, CA 94025, USA plants, biological diversity, and ecosystem goods and services upon which we depend (Ferreira et al. 2011). Manifestations of this eutrophication syndrome have been expressed along many of the world's coastlines, from the Baltic, Black, and Seto Inland Seas to Tokyo, Chesapeake, and Moreton Bays, and coastal waters of the Gulf of Mexico, North Sea, and South China Sea (Boesch 2019).

Protection of estuarine-coastal ecosystems from the eutrophication syndrome has proven to be a difficult policy challenge, partly because of the diverse sources of nutrients delivered to coastal waters from urban and agricultural runoff, atmospheric deposition, and point sources such as municipal wastewater treatment plants. A second challenge, learned from many experiences of nutrient management, is that responses to enrichment vary across ecosystems and they change over time. Thus, protective policies must be placebased and adaptive. This requires that strategies of nutrient management be grounded in information contained in observational data from long-term research and monitoring programs. In particular, policymakers ask of the scientific 
community two essential questions: what is the nutrient status of this estuary, and what does that status mean for developing protective policies? Here we address these questions for San Francisco Bay, a highly enriched estuary where the best path toward nutrient management is not yet clear.

In "Part 1: Nutrient Status of San Francisco Bay," we synthesize different kinds of observational data to assess nutrient status. There is no standard definition of "nutrient status," and we took a comprehensive view of the problem following climate scientists in their assessments of climate change and policy responses to it. The Global Climate Observing System was built around the concept of Essential Climate Variables, defined as a set of variables "that critically contributes to the characterization of Earth's climate" (Bojinski et al. 2014). We assessed the nutrient status of San Francisco Bay by compiling a set of essential variables that critically contribute to the characterization of nutrient pollution in estuaries. These include (1) the environmental setting, including indicators of current water quality condition and factors that regulate conversion of nutrients into algal biomass, (2) identification of nutrient sources and their input rates to the estuary, (3) nutrient concentrations and forms in the estuary, (4) nutrient-based indicators of the potential for algal biomass production and the degree to which that potential is realized, and (5) budgets to estimate the fates of externally derived nitrogen and phosphorus. These variables show that San Francisco Bay has high nutrient loadings and concentrations, the primary source is municipal wastewater, the primary forms are dissolved inorganic $\mathrm{N}$ and $\mathrm{P}$, there is potential for high algal production, that production is not fully realized in today's hydroclimatic setting, but production has increased in recent decades.

In "Part 2: Management Implications and Actions," we discuss implications of this status assessment for resource managers who face challenging decisions of when and how to implement policies of nutrient control. First, we discuss three reasons for concern about the nutrient status of San Francisco Bay: (1) its nitrogen and phosphorus concentrations exceed those in other estuaries impaired by the eutrophication syndrome; (2) warning signs including presence of multiple algal toxins, the trend of increased primary production, and occurrences of large algal blooms during climate anomalies; and (3) model-based projections of future hydroclimatic conditions that could increase the magnitude and frequency of phytoplankton blooms. These concerns have motivated next steps toward a regulatory policy, including development of water quality targets as numerical indicators of nutrient impairment, and determination of the magnitude of nutrient load reduction required to meet those targets.

Our purpose here is to use the San Francisco Bay case study as an example of how scientific information can be acquired and communicated to inform policymakers about the changing state of nutrient pollution, the risks it poses, and scientifically grounded strategies for minimizing those risks.

\section{Study Design and Methods}

\section{The San Francisco Bay System}

San Francisco Bay has been a focus of research by the US Geological Survey (USGS) since 1969 to learn how estuaries respond to hydroclimatic variability and human disturbances such as nutrient enrichment. San Francisco Bay includes two connected, but very different, estuary types. North Bay, which includes Suisun and San Pablo Bays (Fig. 1), is the estuary of California's two largest rivers, the Sacramento and San Joaquin. South Bay is a marine lagoon situated in an urban landscape. Both of these estuaries are connected to the seaward Central Bay, a deep basin strongly influenced by water exchange with the coastal Pacific Ocean (Raimonet and Cloern 2016). The North Bay salinity gradient spans the range from fresh water to nearly full-strength sea water, is displaced seaward $\sim 40 \mathrm{~km}$ by large winter floods (Cloern et al. 2017), and its freshwater source is runoff from California's agricultural Central Valley. The South Bay salinity gradient is weaker, and its freshwater source is urban runoff and effluent from municipal wastewater treatment plants. Water residence time varies seasonally from days to months in North Bay, and from weeks to $>3$ months in South Bay (Walters et al. 1985). In analyses presented here, we consider the San Francisco Bay system as a whole, without consideration of its large spatial variability, to develop an overall assessment of its nutrient status.

\section{Water Samples}

Our sampling in recent years was designed to capture seasonal and spatial variability of nitrogen and phosphorus concentrations and to measure their partitioning into particulate, dissolved, inorganic, and organic components. We collected 512 near-surface water samples by pump on 100 dates between 18 November 2014 and 24 July 2019. Sampling was monthly in North Bay and biweekly-monthly in South Bay and Central Bay. Aliquots for analyses of dissolved inorganic nitrogen (DIN), dissolved inorganic phosphorus (DIP), total dissolved nitrogen (TDN), and total dissolved phosphorus (TDP) were filtered with a syringe using $0.45-\mu \mathrm{m}$ membrane filters. Particulate nitrogen (PN) was measured in particles collected onto precombusted glass fiber (GF/F) filters. Whole water samples were collected for Total Phosphorus (TP) measurements and immediately acidified. All samples were stored at $-20{ }^{\circ} \mathrm{C}$ until analyzed by the USGS National Water Quality Laboratory.

DIN and DIP were measured with an Aquakem 600 automated discrete analyzer using methods of Fishman and Friedman (1989) for nitrite and phosphate, the method of Patton and Kryskalla (2003) for nitrate, and the method of Solorzano (1969) for ammonium with a salt correction factor applied (Stewart and Elliott 1996). TDN was measured in sample filtrates using an alkaline persulfate digestion method 


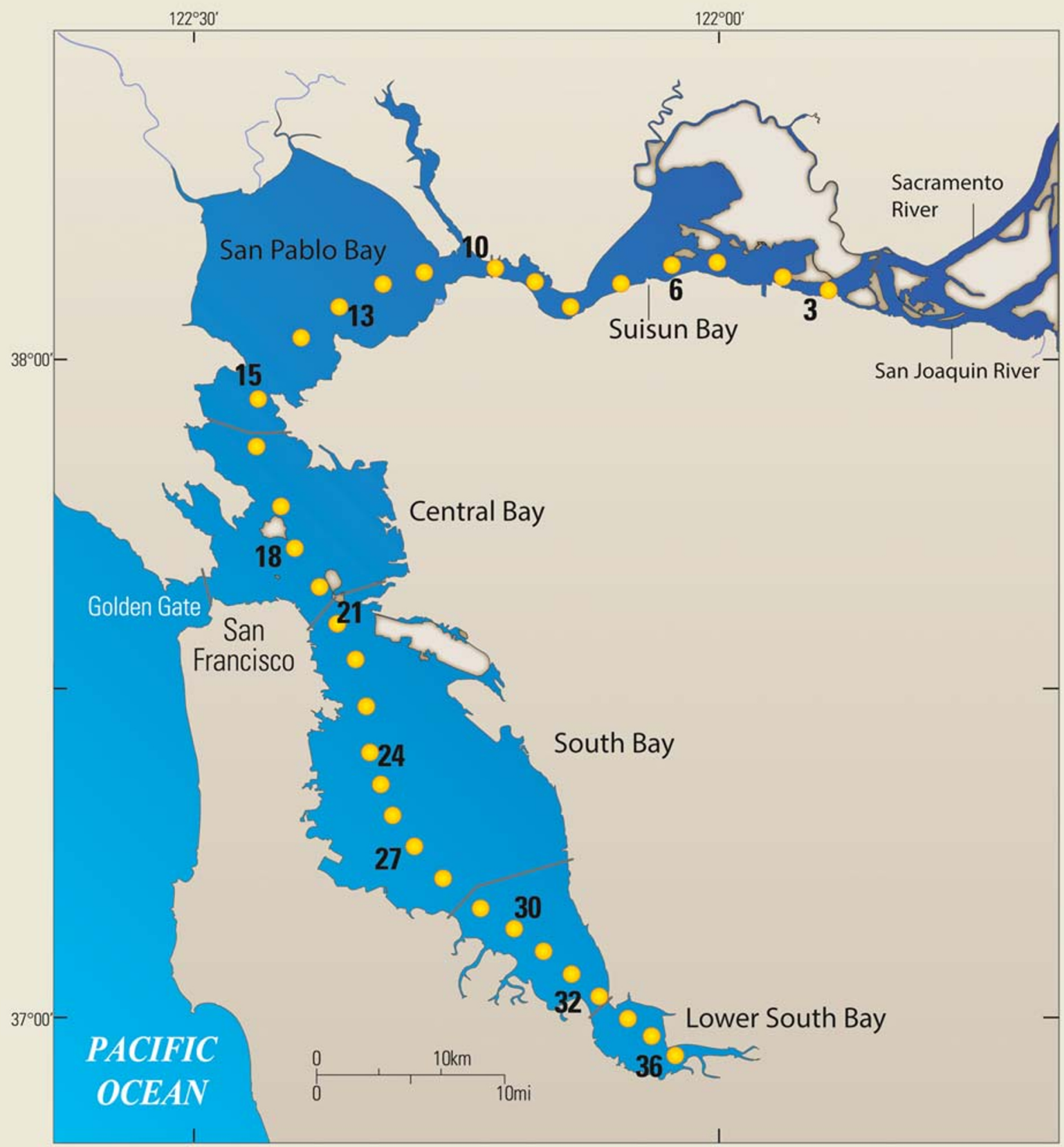

Fig. 1 Map of USGS sampling stations in San Francisco Bay. All components of $\mathrm{N}$ and $\mathrm{P}$ (dissolved, particulate, organic, inorganic) were measured in Lower South Bay (station 36), South Bay (stations 32, 27 , 22), Central Bay (station 18), and North Bay (stations 13, 6). Dissolved

(Patton and Kryskalla 2003). TP was measured in acidified whole-water samples and TDP was measured in filtrates, both using US Environmental Protection Agency (USEPA) method 365.1 (O'Dell 1993). PN was measured using USEPA method 440.0 (Zimmermann et al. 1997).

Aliquots of each sample were also analyzed to measure chlorophyll-a (in cells retained on GF/F filters) and suspended inorganic $\mathrm{N}$ and $\mathrm{P}$ were also measured at stations $30,24,15,9,3$. Chlorophyll-a, salinity, dissolved oxygen, and suspended particulate matter were measured at all stations

particulate matter SPM (collected onto polycarbonate filters having 0.4- $\mu \mathrm{m}$ pore size). Chlorophyll-a concentration (chl-a) was measured fluorometrically using the acidification method on a Turner 10AU or Turner Designs Trilogy fluorometer calibrated with chlorophyll-a standard (Jeffrey et al. 1997; Arar and Collins 1997). SPM concentration was measured as dry-weight mass, with a correction for mass of salt retained 
in filters (Hager 1993). Salinity and temperature were measured using a Sea-Bird Electronics SBE-9plus CTD with an SBE-4C conductivity sensor and SBE-3plus temperature sensor. Dissolved oxygen (DO) was measured with a Sea-Bird Electronics SBE-43 oxygen sensor. Detailed methods for each analysis are described by Schraga and Cloern (2017). Data are accessible from the USGS Science Base repository (Cloern and Schraga 2016; Schraga et al. 2020).

\section{Computed Quantities}

Nutrient analyses included direct measurements of ammonium $\left(\mathrm{NH}_{4}\right)$, nitrate+nitrite $\left(\mathrm{NO}_{32}\right)$, TDN, PN, DIP, TDP, and TP. From these, we computed: DIN as $\mathrm{NO}_{32}+\mathrm{NH}_{4}$, total $\mathrm{N}$ (TN) as PN + TDN, dissolved organic N (DON) as TDN DIN, particulate $\mathrm{P}(\mathrm{PP})$ as TP - TDP, and dissolved organic $\mathrm{P}$ (DOP) as TDP - DIP.

From November 2014 to May 2016, TN was measured directly using the method of Patton and Kryskalla (2003) and PN was computed as the difference between measured TN and TDN. However, some computed PN values were negative. After May 2016, PN was measured directly and TN computed as the sum of PN + TDN as above. We only report $\mathrm{PN}$ and TN based on this approach.

We estimated the components of particulate $\mathrm{N}$ and $\mathrm{P}$ associated with suspended sediments and phytoplankton biomass using multiple linear regressions of PN $(\mu \mathrm{M} \mathrm{N})$ and $\mathrm{PP}(\mu \mathrm{M}$ $\mathrm{P})$ as functions of SPM $\left(\mathrm{mg} \mathrm{l}^{-1}\right)$ and chl-a $\left(\mu \mathrm{g} \mathrm{l} \mathrm{l}^{-1}\right)$ :

$\mathrm{PN}=2.70+0.101 \times \mathrm{SPM}+0.677 \times \mathrm{chl}-\mathrm{a} \quad\left(\right.$ adjusted $\left.R^{2}=0.85\right)$

$\mathrm{PN}=0.32+0.025 \times \mathrm{SPM}+0.031 \times \mathrm{chl}-\mathrm{a} \quad\left(\right.$ adjusted $\left.R^{2}=0.69\right)$

From these regressions, we estimated the concentrations of nitrogen $\left(\mathrm{N}_{\text {sed }}, \mathrm{N}_{\text {phyt }}\right)$ and phosphorus $\left(\mathrm{P}_{\text {sed }}, \mathrm{P}_{\text {phyt }}\right)$ bound to sediments and in phytoplankton biomass:

$$
\begin{aligned}
& \mathrm{N}_{\text {sed }}=0.101 \times \mathrm{SPM} \\
& \mathrm{N}_{\text {phyt }}=0.677 \times \text { chl-a } \\
& \mathrm{P}_{\text {sed }}=0.025 \times \mathrm{SPM} \\
& \mathrm{P}_{\text {phyt }}=0.031 \times \text { chl }-\mathrm{a}
\end{aligned}
$$

Regression coefficients show that a gram of sediment in surface waters of San Francisco Bay contains, on average, $1.4 \mathrm{mg} \mathrm{N}$ and $0.78 \mathrm{mg}$ P. Intercepts of the regression equations represent mean concentrations of particulate nitrogen $\left(\mathrm{PN}_{\text {other }}=2.70 \mu \mathrm{M}\right)$ and phosphorus $\left(\mathrm{PP}_{\text {other }}=0.32 \mu \mathrm{M}\right)$ associated with other particles such as free-living bacteria and microzooplankton.

\section{Cross-Ecosystem Comparisons}

As a frame of reference for interpreting nutrient concentrations and chemical forms in San Francisco Bay, we compared our measurements against similar measurements made in Chesapeake Bay. Data were accessed 9 July 2018 from websites of the Chesapeake Bay Program (http://data. chesapeakebay.net/WaterQuality). We aggregated Chesapeake Bay data collected January 2013 through December 2017 in surface waters at 6 sites $(2.1,3.3 \mathrm{C}, 4.3 \mathrm{C}$, $5.2,6.1,7.4)$ distributed along the estuarine salinity gradient.

\section{Part 1: Nutrient Status of San Francisco Bay}

There is no standard method for assessing the nutrient status of estuaries. We took a comprehensive view and built an assessment of nutrient status that has five components. Each component was grounded in data, and each provides a different perspective for understanding the degree of nutrient enrichment in this estuary and its meaning for regulatory protection of water and habitat quality. Our assessment begins with a description of the estuarine setting of San Francisco Bay as summaries of water quality metrics that define the ecosystem as habitat for phytoplankton production. Second, we describe the sources and rates of externally supplied N and P to San Francisco Bay and place those loadings in a global perspective. Third, we synthesize measurements of nutrient concentrations and chemical forms in the estuary and give meaning to those measurements by comparing them with measurements in Chesapeake Bay as an example of an estuary degraded by nutrient enrichment. Fourth, we develop indicators of $\mathrm{N}$ and $\mathrm{P}$ availability in San Francisco Bay relative to phytoplankton growth requirements and their potential for biomass accumulation. Finally, we construct a nutrient budget for San Francisco Bay as a foundation for understanding the fate of nutrients delivered externally, and for developing policies to protect its water quality from the harmful consequences of nutrient enrichment.

\section{The Estuarine Setting}

Water samples were collected along the salinity gradients of North and South Bay. Hydrologic conditions varied seasonally between high-flow winters and low-flow summers and included extremes of low inflow during 2014 and 2015 (during the driest period on record) and high inflow during 2016 and 2017 (the wettest period on record). Surface salinity in those samples ranged from 0.1 to 33.5 , and the median was 25.9 (Fig. 2). Therefore, most samples were collected in estuarine waters having a larger fraction of seawater than fresh water. This reflects the saline character of South, Central, and San Pablo Bays that contain $94 \%$ of the water volume in this estuarine system (Jassby et al. 1993). Most of the 134 salinity measurements less than 20 (Fig. 2) represented sampling along the landward reaches of the North Bay salinity gradient. Others represented events of high runoff from storms during winter and spring of 2016 and 2017. 

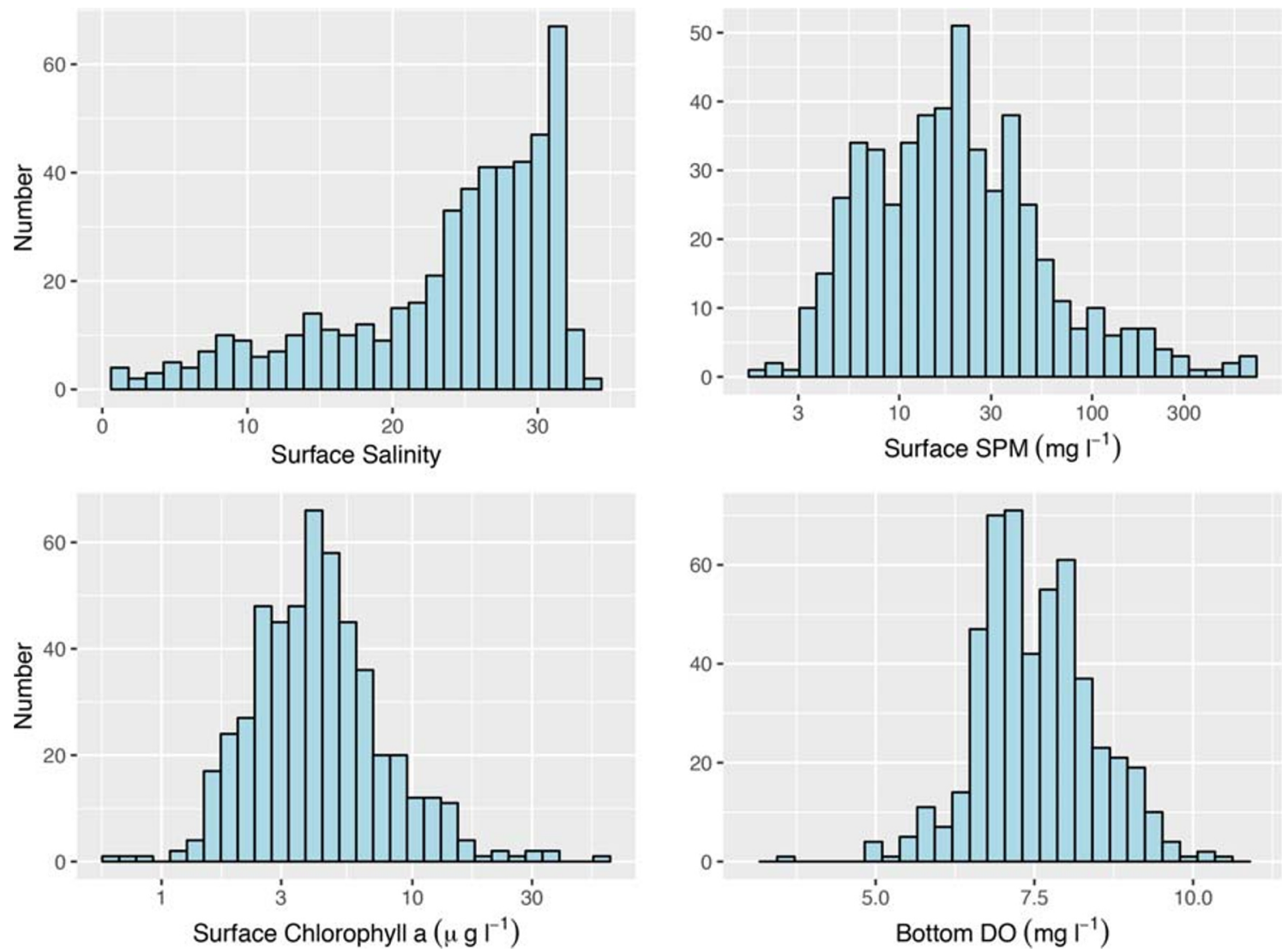

Fig. 2 Distributions of surface salinity, SPM, and chl-a and bottom DO measured along the salinity gradients of San Francisco Bay from November 2014 through July 2019. Note log scales in distributions of SPM and chl-a

San Francisco Bay is a turbid estuary, and that turbidity is derived primarily from large sediment inputs from its urban watershed and the Sacramento-San Joaquin Rivers (Schoellhamer 2011). The fine-grained sediments are suspended by bottom stresses from wind waves and tidal currents (Schoellhamer 1996), and their concentrations are highly variable seasonally and along the salinity gradients (Cloern et al. 2017). In this study, surface SPM concentrations ranged from 2 to $703 \mathrm{mg} \mathrm{l}^{-1}$ (Fig. 2). The median SPM was 19 and the mean $39 \mathrm{mg} \mathrm{l}^{-1}$. This difference between median and mean reflects events of extremely high surface SPM, exceeding $400 \mathrm{mg} \mathrm{l}^{-1}$ in Lower South Bay and $100 \mathrm{mg} \mathrm{l}^{-1}$ in South Bay, during storms and high-energy spring tides.

We measured surface chl-a as an index of phytoplankton biomass in the photic zone. Chl-a concentration ranged between 1 and $52 \mu \mathrm{g} \mathrm{l}^{-1}$; the median was 4.0 and the mean was $5.2 \mu \mathrm{g} \mathrm{l}^{-1}$ (Fig. 2). This difference was primarily attributed to spring blooms (chl-a $>10 \mu \mathrm{g} \mathrm{l}^{-1}$ ) in South Bay and larger spring blooms (chl-a $>25 \mu \mathrm{g} \mathrm{l}^{-1}$ ) in Lower South Bay. Blooms in this estuary are events of biomass production by large cells, particularly diatoms (Cloern 2017).

Dissolved oxygen concentrations in bottom waters ranged from 3.6 to $10.6 \mathrm{mg} \mathrm{l}^{-1}$; the mean and median were 7.5 and $7.4 \mathrm{mg}^{-1}$, respectively (Fig. 2). Twenty-two samples had bottom DO $<6 \mathrm{mg} \mathrm{l}^{-1}$. Eighteen of these occurred in the Lower South Bay during warm months, and the other 4 in Central Bay. The Lower South Bay is enriched in organic matter, including phytoplankton biomass produced in its shallow sloughs and ponds (Thebault et al. 2008), so lowest oxygen concentrations in this region are attributed partly to its high metabolism (MacVean et al. 2018). Low-DO events in Central Bay are associated with intrusions of recently upwelled deep ocean water (Cloern et al. 2017) and therefore are unrelated to anthropogenic nutrient enrichment.

These results show that the environmental setting of San Francisco Bay includes a wide range of estuarine environments along its two salinity gradients. Phytoplankton biomass (chl-a) is low relative to some other estuaries (Cloern and Jassby 2008). Exceptions occur as (usually shortlived) blooms. The estuary has high SPM concentrations, and light limitation of growth by sediment-derived turbidity constrains phytoplankton production (Cole and Cloern 1987). Bottom waters are usually well oxygenated (Fig. 2)-only 1 of 507 measured concentrations was less than the state's Water Quality DO Criterion of $5 \mathrm{mg} \mathrm{l}^{-1}$ (Sutula et al. 2017). Therefore, deep waters of San Francisco Bay do not have the seasonal anoxia or hypoxia characteristic of many nutrient-enriched estuaries. Tidal sloughs draining 
into Lower South Bay do experience DO $<5 \mathrm{mg} \mathrm{l}^{-1}$, particularly in summer, and this may create localized zones of reduced habitat quality for some fish species (MacVean et al. 2018).

\section{External Sources of $\mathbf{N}$ and $\mathbf{P}$}

San Francisco Bay receives nutrient inputs from three key anthropogenic sources: effluent discharge from 42 publicly owned treatment works (POTWs) and 6 refineries; storm water runoff from the surrounding urban watershed; and outflow from the Sacramento-San Joaquin Delta that includes nutrients from agricultural runoff and from the Sacramento Regional Wastewater Treatment Facility (SRWTF). Historical data are not available to quantify inputs of total $\mathrm{N}$ or P, but Novick and Senn (2014) compiled inputs of dissolved inorganic $\mathrm{N}$ and $\mathrm{P}$. Mean daily loadings, based primarily on measurements from 2006 to 2014, were 73.8 (metric) tons of DIN and 6.3 tons of DIP (Table 1). The largest source is POTWs, contributing $62 \%$ of both DIN and DIP input from cumulative discharge of 500 million gallons of treated effluent per day. Storm water contributes $15 \%$ of DIN and $21 \%$ of DIP input (Table 1), and nutrient input from Delta outflow includes large fractions of DIN and DIP from the SRWTF (Hager and Schemel 1992). Therefore, San Francisco Bay is enriched in N and $\mathrm{P}$ because of its urban setting.

The inputs listed in Table 1 are incomplete measures of total nutrient loadings because they do not include particulate or organic forms of $\mathrm{N}$ or $\mathrm{P}$. We can estimate these components of wastewater because DIN and DIP account for $89 \%$ of TN and $78 \%$ of TP, respectively (Novick and Senn 2014). This implies daily loadings of $82.9 \mathrm{t}$ of $\mathrm{N}$ and $8.1 \mathrm{t}$ of $\mathrm{P}$ from all measured sources (Table 1). No information is available for assessing organic or particulate inputs from refineries or urban runoff, or for assessing nutrient inputs from atmospheric deposition or groundwater. However, we can conclude from the available measurements that daily inputs to San Francisco Bay exceed $82.9 \mathrm{t}$ of nitrogen and $8.1 \mathrm{t}$ of phosphorus.

We place these loadings in a global context by comparing them against $\mathrm{N}$ and $\mathrm{P}$ inputs to other estuaries. The area of San Francisco Bay at mean tide level is $4.4 \times 10^{8} \mathrm{~m}^{2}$ (Jassby et al. 1993 ), so areal loadings from Table 1 are $>$ $69 \mathrm{~g} \mathrm{TN} \mathrm{m}^{-2}$ year $^{-1}$ and $>6.7 \mathrm{~g} \mathrm{TP} \mathrm{m}^{-2}$ year $^{-1}$. These values

Table 1 Mean daily inputs of DIN and DIP to San Francisco Bay, based on compilations of measured (POTWs, refineries, Delta outflow) and modeled (storm water) loadings from measurements between 2006 and place San Francisco Bay in the 87th percentile of N loadings compiled from 163 estuaries, and in the 91st percentile of $\mathrm{P}$ loading across a range of estuarine-coastal ecosystem types. By global standards, then, San Francisco Bay has very high external inputs of both nitrogen and phosphorus. Its areal loading rates exceed those in many estuaries and bays where water and habitat quality have been degraded by nutrient enrichment, such as the Neuse River Estuary, Long Island Sound, Chesapeake Bay, Venice Lagoon, and the Odense fjord (Fig. 3).

\section{Nutrient Concentrations and Chemical Forms}

The third component of our assessment includes measurements of total nitrogen and phosphorus concentrations, and their partitioning into organic, inorganic, particulate, and dissolved forms. The long history of nutrient measurements in San Francisco Bay has focused almost exclusively on the dissolved inorganic components. Here, we include recent measurements of the other components to give a more complete assessment of the sizes and biological availability of the $\mathrm{N}$ and $P$ stocks in surface waters. We also estimated the fractions of those stocks assimilated into phytoplankton biomass and the remaining fractions available to support additional biomass production.

Frequency distributions (Fig. 4) show the variability of total $\mathrm{N}$ and $\mathrm{P}$ and their individual components captured in seasonal and spatial sampling from November 2014 through July 2019. Total nutrient concentrations ranged from 18.1 to $218 \mu \mathrm{M}$ TN and from 1.4 to $35.5 \mu \mathrm{M}$ TP. The dissolved inorganic forms ranged from 1.3 to $151 \mu \mathrm{M}$ DIN (most as nitrate) and from 1.0 to $28.8 \mu \mathrm{M}$ DIP. The distribution of TN was skewed toward very high values, with 49 measurements exceeding $100 \mu \mathrm{M}$ (Fig. 4). These were all from samples collected in Lower South Bay. The distributions of TP and DIP were bimodal (Fig. 4), reflecting higher phosphorus concentrations in South Bay than in North Bay (Conomos et al. 1979).

We used the means of these measurements as indicators of the nutrient status of the entire San Francisco Bay system. These indicators show that, on average, $82 \%$ of the nitrogen in surface waters was in a dissolved form, $59 \%$ as DIN and $23 \%$ as DON (Fig. 5). Most (77\%) of the phosphorus was also

2014 (Novick and Senn 2014). The bottom row compares DIN/DIP ratios of the four sources and their loading-weighted mean. The last column adds estimates of wastewater inputs of organic and particulate $\mathrm{N}$ and $\mathrm{P}$

\begin{tabular}{lllllll}
\hline & 42 POTWs & 6 Refineries & Storm water & Delta & Total DIN, DIP & Total TN, TP \\
\hline N Input $\left(\mathrm{t} \mathrm{day}^{-1}\right)$ & 45.8 & 1 & 10.8 & 16.2 & 73.8 & $>82.9$ \\
P Input $\left(\mathrm{t} \mathrm{day}^{-1}\right)$ & 3.9 & 0.1 & 1.3 & 1 & 6.3 & $>8.1$ \\
DIN:DIP $(\mathrm{mol} / \mathrm{mol})$ & 26 & 22 & 18 & 36 & 26 & \\
\hline
\end{tabular}


Fig. $3 \log 10$ of annual areal loadings of $\mathrm{N}$ and $\mathrm{P}$ to estuaries and bays around the world, ranked from lowest to highest. $\mathrm{N}$ loadings are inputs of either DIN, TDN, or TN. P loadings are TP. Loadings to San Francisco Bay are underestimates of TN and TP inputs because they do not include organic or particulate inputs from refineries, urban runoff, or atmospheric deposition. Loadings to other estuaries were obtained from previously published compilations (Dettmann 2001; McGlathery et al. 2007; Josefson and Rasmussen 2000; Boynton et al. 1996; Moorman et al. 2014)

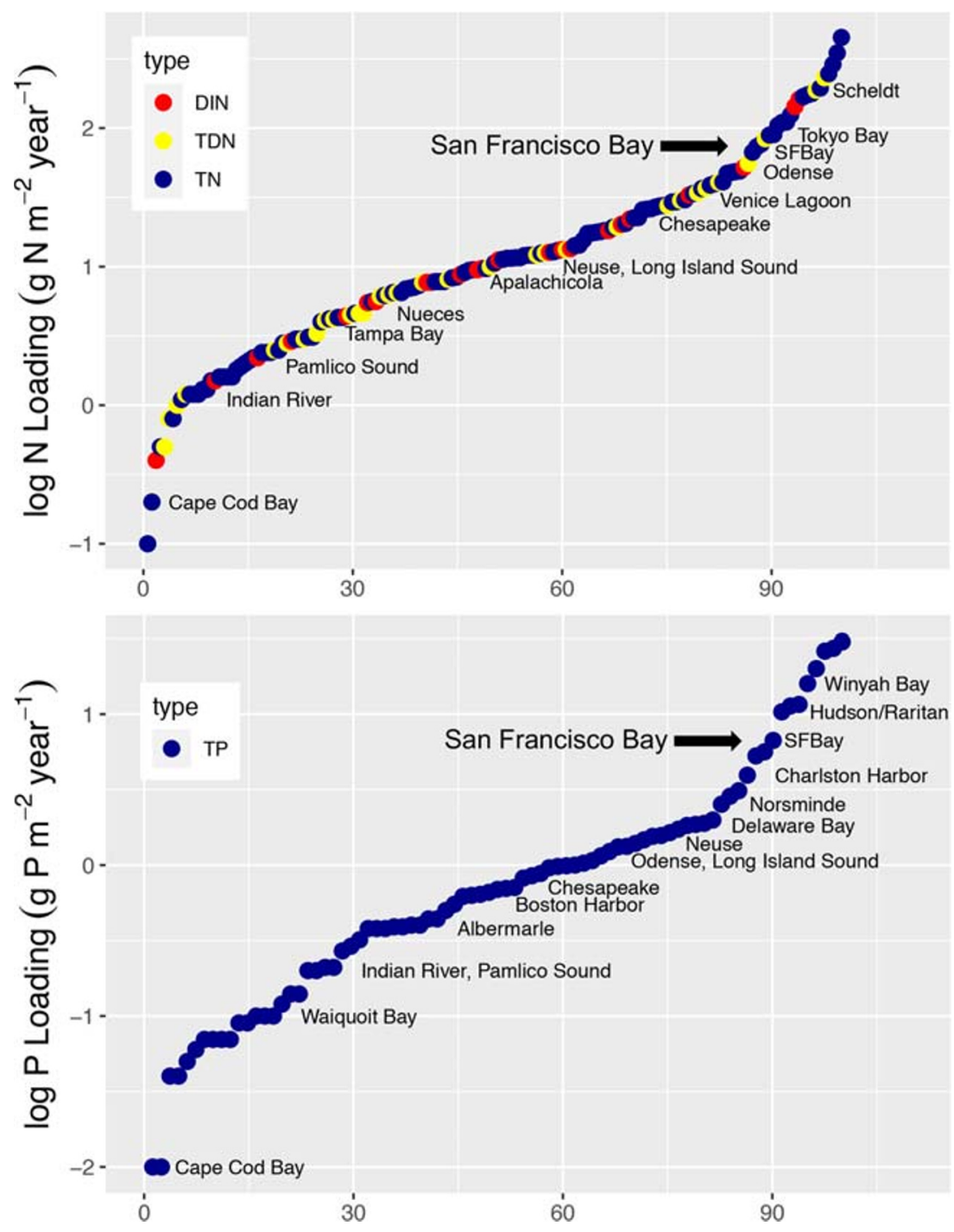

in dissolved form, primarily as DIP (70\%). On average, the fractions of total $\mathrm{N}$ and $\mathrm{P}$ contained in phytoplankton biomass were small, only $7 \%$ and $3 \%$, respectively. The fractions of total $\mathrm{N}$ and $\mathrm{P}$ associated with suspended sediments averaged $5 \%$ and $13 \%$, respectively. A few samples deviated substantially from these means during phytoplankton blooms or events of sediment resuspension. The phytoplankton components reached maximum values of $\mathrm{N}_{\text {phyt }}=35.3 \mu \mathrm{M} \mathrm{N}$ and $\mathrm{P}_{\text {phyt }}=1.6 \mu \mathrm{M}$ P during the largest bloom (chl-a $=$ $52.2 \mu \mathrm{g}^{-1}$ ). The sediment component reached a maximum $\mathrm{N}_{\text {sed }}=71.0 \mu \mathrm{M} \mathrm{N}$ and $\mathrm{P}_{\text {sed }}=17.6 \mu \mathrm{M} \mathrm{P}$ in the sample having highest SPM concentration (703 $\mathrm{mg}^{-1}$ ).

These results support three conclusions about the nutrient status of San Francisco Bay. First, N and P concentrations in surface waters are high and mostly in dissolved forms that could be converted into phytoplankton biomass but are not, except during short-lived bloom events. Second, historical measurements of only dissolved inorganic forms have under-estimated total $\mathrm{N}$ and $\mathrm{P}$ by $41 \%$ and $30 \%$, respectively.
Some of the other components, in particular DON (mean $16.2 \mu \mathrm{M}$ ) and PP (mean 1.5 $\mathrm{MM}$ ), are accessible to phytoplankton (e.g., Bronk et al. 2007; Ellison and Brett 2006) and therefore can support biomass growth to levels beyond those set by the availability of DIN or DIP alone. Finally, the extreme values of chl-a (highest), bottom DO (lowest), SPM (highest), TN and TP (highest) all occurred in Lower South Bay. This small region receives discharge from one of the largest wastewater treatment plants, is connected to shallow high-productivity ponds, and its water exchange with larger South Bay is restricted by a topographic constriction (Fig. 1). Therefore, the nutrient status of Lower South Bay is distinct from that of the entire Bay system that we assess here.

By themselves, the numbers presented here may convey little information to policymakers responsible for managing nutrient pollution and its effects. As one context for understanding the nutrient status of San Francisco Bay, we compared its mean concentrations and forms of $\mathrm{N}$ and $\mathrm{P}$ with mean measurements made in surface waters along the salinity 

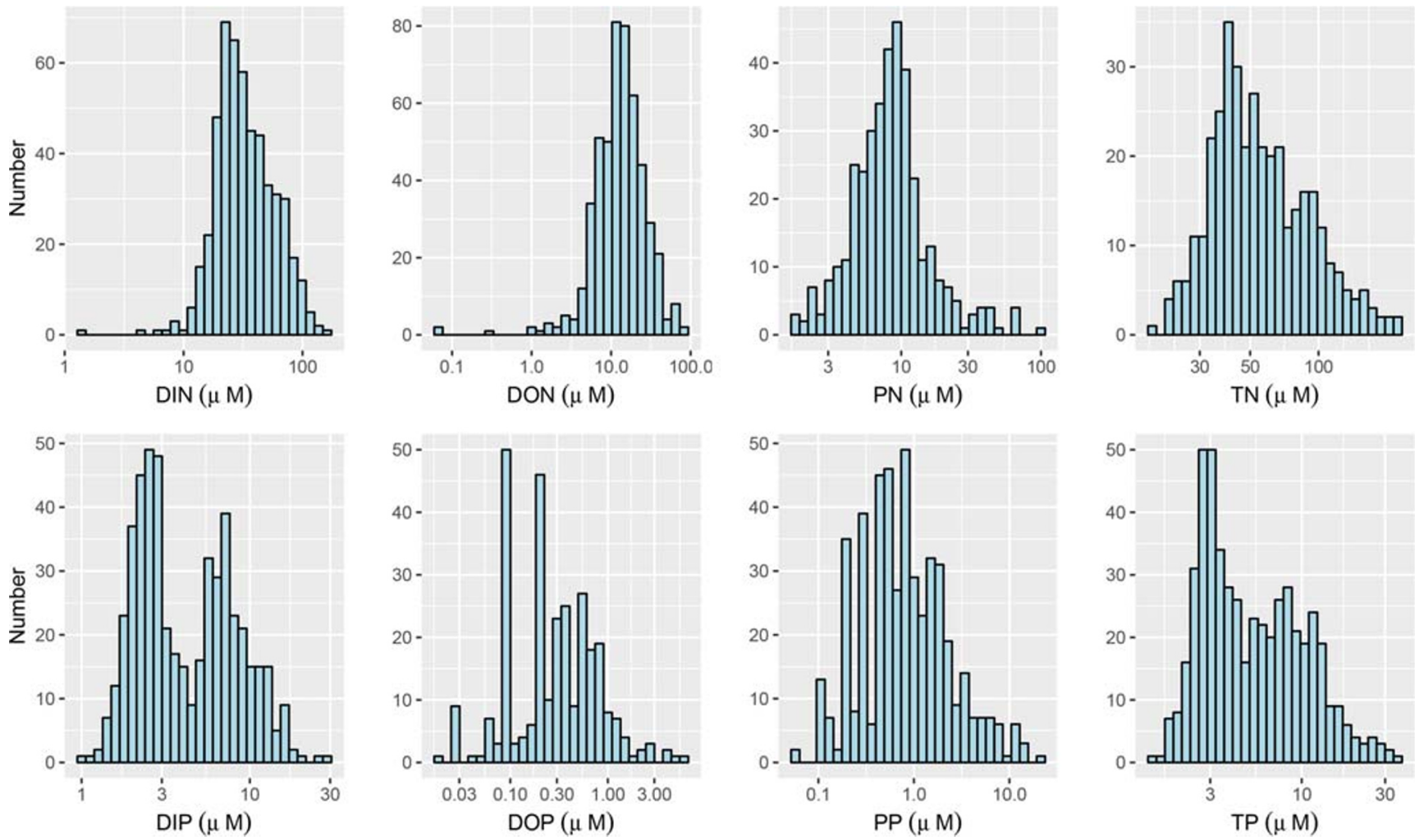

Fig. 4 Distributions of four different components of the nitrogen and phosphorus stocks measured along the salinity gradients of San Francisco Bay from November 2014 through July 2019. Note log scales of all $x$-axes

gradient of Chesapeake Bay. Total and total dissolved $\mathrm{N}$ and $\mathrm{P}$ all have higher mean concentrations in San Francisco Bay than in Chesapeake Bay (Table 2). Mean $\mathrm{NO}_{32}$ is about double, $\mathrm{NH}_{4}$ is more than five times higher, $\mathrm{TP}$ is more than six times higher, and DIP is 26 times higher than in Chesapeake Bay (Table 2). The nutrient status of Chesapeake Bay provides a useful context because it is a high-profile example of an estuary impaired by nutrient enrichment through its elevation of primary productivity and chl-a, leading to decreased water transparency, loss of seagrasses, increased system metabolism and areal extent of hypoxia (Kemp et al. 2005). San Francisco Bay has higher $\mathrm{N}$ and especially higher $\mathrm{P}$ concentrations, so its potential for these kinds of water-quality impairments exceeds that of Chesapeake Bay.

\section{Indicators of Nutrient Enrichment}

Nutrient enrichment has important implications for phytoplankton production and biomass accumulation. We used three indicators based on nutrient measurements to assess (1) the potential for biomass production in San Francisco Bay, (2) the degree to which that potential is currently realized, and (3) the availability of $\mathrm{N}$ and $\mathrm{P}$ relative to phytoplankton requirements.

Nutrient Limitation Index The rates of phytoplankton nutrient uptake and growth follow the hyperbolic Michaelis-Menten function that is shaped by the half-saturation constant $K$, the nutrient concentration where uptake or growth rate is half maximal. Characteristic values for marine diatoms are $K_{\mathrm{N}}=$ $1.6 \mu \mathrm{M}$ for DIN uptake and $K_{\mathrm{P}}=0.24 \mu \mathrm{M}$ for DIP uptake (Sarthou et al. 2005). From these, we computed indices of nutrient limitation as the percentage of maximal uptake rate supported by measured DIN and DIP concentrations:

$$
\begin{aligned}
& \mathrm{N}_{\text {limit }}=100 \times \mathrm{DIN} /(\mathrm{DIN}+1.6) \\
& \mathrm{P}_{\text {limit }}=100 \times \mathrm{DIP} /(\mathrm{DIP}+0.24)
\end{aligned}
$$

These are conservative estimates of maximum growth rate because they do not include dissolved organic or sedimentassociated components as additional sources of $\mathrm{N}$ and $\mathrm{P}$ to support phytoplankton growth. The mean values from 2014 to 2019 measurements were $\mathrm{N}_{\text {limit }}=95 \%$ and $\mathrm{P}_{\text {limit }}=94 \%$ (Table 2). For comparison, mean indices in Chesapeake Bay were $\mathrm{N}_{\text {limit }}=60 \%$ and $\mathrm{P}_{\text {limit }}=33 \%$ (Table 2). Thus, phytoplankton growth in Chesapeake Bay is more frequently limited by low DIN, and especially low DIP, than in San Francisco Bay. Therefore, one consequence of large DIN and DIP inputs to San Francisco Bay is that N and P concentrations are usually high enough to support near-maximal uptake and growth rates. Thus, enrichment at this level creates a potential for high biomass production and accumulation. 


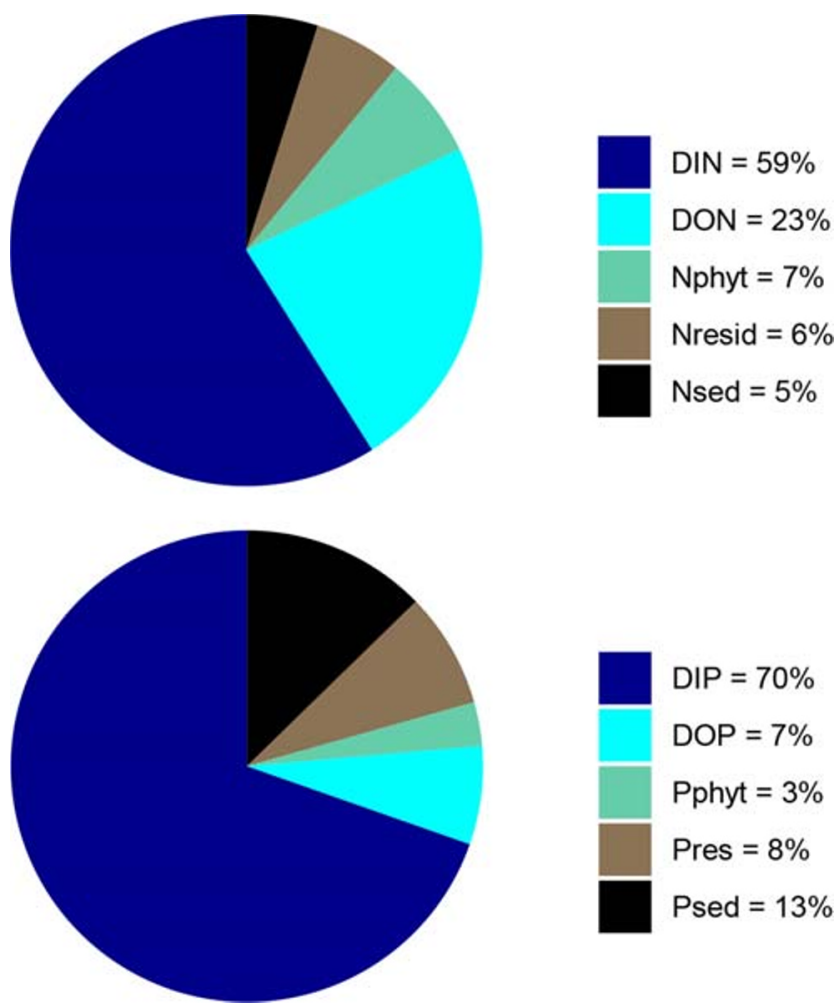

Fig. 5 Pie charts showing the overall mean partitioning of $\mathrm{N}$ and $\mathrm{P}$ into five components, based on surface samples collected along the salinity gradients of San Francisco Bay from November 2014 through July 2019. $\mathrm{DIN}$ and DIP $=$ dissolved inorganic $\mathrm{N}$ and $\mathrm{P} ; \mathrm{DON}$ and DOP $=$ dissolved organic $\mathrm{N}$ and $\mathrm{P} ; \mathrm{N}_{\text {phyt }}$ and $\mathrm{P}_{\text {phyt }}=$ the mean phytoplankton component estimated from regression slopes of PN and PP on chl-a; $\mathrm{N}_{\text {sed }}$ and $\mathrm{P}_{\text {sed }}=$ the mean sediment-bound component estimated from regression slopes of PN and PP on SPM; $\mathrm{N}_{\text {resid }}$ and $\mathrm{P}_{\text {resid }}$ are residual components of TN and TP not associated with the other four components

Nutrient Utilization Efficiency We computed a second index to measure the degree to which this potential for high biomass production is realized in San Francisco Bay. The index follows Monbet (1992), who compared chl-a and DIN relationships as an index of nutrient utilization efficiency across 40 estuarine-coastal ecosystems. We used chl-a/DIN as an index of the ratio of phytoplankton biomass to the stock of DIN available to produce additional biomass. Similarly, we used chl-a/DIP as an index of $\mathrm{P}$ utilization efficiency. Large values indicate high ecosystem efficiency at converting dissolved inorganic nutrients into phytoplankton biomass. Mean ratios chl-a/DIN and chl-a/DIP were 0.1 and 1.0, respectively, in San Francisco Bay compared to 0.6 and 53.4 in Chesapeake Bay (Table 2). Based on this index, the Chesapeake Bay system is 6 and 53 times more efficient at transforming inorganic $\mathrm{N}$ and $\mathrm{P}$ stocks into phytoplankton biomass. The lower mean efficiencies of $\mathrm{N}$ and $\mathrm{P}$ utilization in San Francisco Bay show that its nutrient-based potential for high biomass production is usually not realized. Exceptions occur during the largest spring blooms when most or all of the DIN pool is converted into biomass (Cloern 1996).
Nutrient Stoichiometry Lastly, we used N/P ratios in San Francisco Bay to identify the nutrient element that could limit phytoplankton growth if utilization efficiency increased. A common approach (e.g., Boynton et al. 2008) is to compare $\mathrm{N} / \mathrm{P}$ ratios against the Redfield ratio ( $16 \mathrm{~mol} \mathrm{~N}$ per mole of $\mathrm{P}$ ), an index of the relative $\mathrm{N}$ and $\mathrm{P}$ requirements of phytoplankton. There is no standard approach for the nutrient forms used to compare against the Redfield ratio, so we used three: DIN/ DIP, TDN/TDP, and TN/TP. There also is not universal agreement that 16 is the best representation of phytoplankton nutrient stoichiometry because N/P ratios of phytoplankton in culture are highly variable and have a mean of 10 (Geider and La Roche 2002). None of the three N/P ratios measured in San Francisco Bay had mean values exceeding 16 (Table 2). Based on the Redfield benchmark, this indicates that $\mathrm{N}$ is less available than $\mathrm{P}$ relative to phytoplankton requirements. However, the mean DIN/DIP in San Francisco Bay was 8.7 (Table 2), close to the mean N/P ratio of marine phytoplankton in culture. Therefore, our conclusions about the most-limiting nutrient vary depending on the threshold N/P ratio assumed. Additional uncertainty arises in the interpretation of N/P ratios in San Francisco Bay because the range across all 3 indices (0.7 to 64.9) spans far below and far above the threshold N:P ratios of either 10 or 16 (Table 2). This large seasonal and spatial variability of N/P ratios is one reason why estuarine scientists recommend reduction of both $\mathrm{N}$ and $\mathrm{P}$ loadings to remediate nutrient-impaired coastal waters (Paerl et al. 2016; Conley et al. 2009).

\section{Where Does All This N and P Go?}

Nutrients delivered to estuaries can have three fates: accumulation, export, or loss to internal processes. Few of these processes have been measured directly, but we synthesized the available information to construct budgets and estimate the fate of the $>80 \mathrm{t}$ of $\mathrm{N}$ and $>8 \mathrm{t}$ of $\mathrm{P}$ delivered daily to San Francisco Bay.

Accumulation in Bay Waters We first consider accumulation because annual nutrient budgets are often built from an assumption that inputs and losses are balanced-i.e., there is no accumulation over an annual cycle (e.g., Dettmann 2001). We used bay-wide mean concentrations of DIN and DIP over the period 2009-2018 (the most recent complete decade of measurements) to determine if dissolved inorganic $\mathrm{N}$ or $\mathrm{P}$ are accumulating in San Francisco Bay. For each year, we computed mean DIN and DIP in each region, then calculated bay-wide means from regional mean concentrations weighted by the volume of each region (from Table 1; Smith and Hollibaugh (2006)). The Mann Kendall trend test (R package wql; Jassby and Cloern (2016)) on these annualized series showed that trends were small, $-0.20 \mu \mathrm{M}$ DIN year ${ }^{-1}$ and $0.03 \mu \mathrm{M}$ 
Table 2 Summary statistics of the different forms of $\mathrm{N}$ and $\mathrm{P}$ measured in surface waters of San Francisco Bay from November 2014 through July 2019. Included for comparison are means of comparable measurements made along the salinity gradient of Chesapeake Bay (CB) from 2013 through 2017. Also shown are indicators of nutrient limitation, utilization efficiency, and stoichiometry

\begin{tabular}{|c|c|c|c|c|c|c|}
\hline Nutrient form & Method & $\begin{array}{l}\text { Number of } \\
\text { measurements }\end{array}$ & $\begin{array}{l}\text { Minimum } \\
(\mu \mathrm{M})\end{array}$ & $\begin{array}{l}\text { Maximum } \\
(\mu \mathrm{M})\end{array}$ & $\begin{array}{l}\text { Mean } \\
(\mu \mathrm{M})\end{array}$ & $\begin{array}{l}\text { Mean } \\
\text { CB }\end{array}$ \\
\hline $\mathrm{TN}=$ total $\mathrm{N}$ & Computed: PN + TDN & 369 & 18.1 & 217.8 & 63.3 & 47.0 \\
\hline $\mathrm{PN}=$ particulate $\mathrm{N}$ & $\begin{array}{l}\text { USEPA Method } 440.0 \text { (Zimmermann } \\
\text { et al. 1997) }\end{array}$ & 369 & 1.7 & 97.1 & 10.6 & 12.4 \\
\hline $\mathrm{TDN}=$ total dissolved $\mathrm{N}$ & Patton and Kryskalla (2003) & 510 & 8.6 & 196 & 53.8 & 34.8 \\
\hline $\mathrm{DON}=$ dissolved organic $\mathrm{N}$ & Computed: TDN $-\mathrm{NO}_{32}-\mathrm{NH}_{4}$ & 498 & 0.1 & 85.7 & 16.2 & 18.2 \\
\hline $\mathrm{NO}_{32}=$ nitrate + nitrite & Fishman and Friedman (1989) & 511 & 0.8 & 136 & 31.5 & 15.6 \\
\hline $\mathrm{NH}_{4}=$ ammonium & $\begin{array}{l}\text { Solorzano (1969); Stewart and Elliott } \\
\text { (1996) }\end{array}$ & 510 & 0.3 & 22.8 & 6.9 & 1.3 \\
\hline $\mathrm{N}_{\text {phyt }}=\mathrm{N}$ in phytoplankton & Computed: $0.677 \times$ chl-a & 511 & 0.7 & 35.3 & 3.5 & 6.7 \\
\hline $\begin{array}{l}\mathrm{N}_{\text {spm }}=\mathrm{N} \text { on suspended } \\
\text { sediments }\end{array}$ & Computed: $0.101 \times \mathrm{SPM}$ & 511 & 0.2 & 71.0 & 3.9 & 0.5 \\
\hline $\mathrm{TP}=$ total $\mathrm{P}$ & USEPA Method 365.1 (O'Dell 1993) & 511 & 1.4 & 35.5 & 6.6 & 1.0 \\
\hline $\mathrm{PP}=$ particulate $\mathrm{P}$ & Computed: TP - TDP & 480 & 0.0 & 22.4 & 1.5 & 0.4 \\
\hline $\mathrm{TDP}=$ total dissolved $\mathrm{P}$ & Patton and Kryskalla (2003) & 511 & 0.9 & 29.3 & 5.3 & 0.4 \\
\hline $\mathrm{DOP}=$ dissolved organic $\mathrm{P}$ & Computed: TDP - DIP & 330 & 0.0 & 6.6 & 0.4 & 0.2 \\
\hline $\mathrm{DIP}=$ dissolved inorganic $\mathrm{P}$ & Fishman and Friedman (1989) & 511 & 1.0 & 28.8 & 5.2 & 0.2 \\
\hline $\mathrm{P}_{\text {phyt }}=\mathrm{P}$ in phytoplankton & Computed: $0.031 \times$ chl-a & 511 & 0.0 & 1.6 & 0.2 & 0.2 \\
\hline $\begin{array}{l}\mathrm{P}_{\text {spm }}=\mathrm{P} \text { on suspended } \\
\text { sediments }\end{array}$ & Computed: $0.025 \times \mathrm{SPM}$ & 511 & 0.1 & 17.6 & 1.0 & 0.3 \\
\hline \multicolumn{7}{|c|}{ Nutrient limitation index ( $\%$ maximum uptake rate) } \\
\hline $\mathrm{N}_{\text {limit }}$ & Computed: DIN/(DIN + 1.6) & 511 & $45 \%$ & $99 \%$ & $95 \%$ & $60 \%$ \\
\hline $\mathrm{P}_{\text {limit }}$ & Computed: DIP/(DIP + 0.24) & 511 & $81 \%$ & $99 \%$ & $94 \%$ & $33 \%$ \\
\hline \multicolumn{7}{|l|}{ Nutrient utilization efficiency } \\
\hline Nitrogen & $\begin{array}{l}\text { Computed: mean chlorophyll-a /mean } \\
\text { DIN }\end{array}$ & 510 & & & 0.1 & 0.6 \\
\hline Phosphorus & Computed: mean chlorophyll-a /mean DIP & 510 & & & 1.0 & 53.4 \\
\hline \multicolumn{7}{|l|}{ Nutrient stoichiometry } \\
\hline Inorganic & Computed: DIN/DIP & 511 & 0.7 & 25.8 & 8.7 & \\
\hline Dissolved & Computed: TDN/TDP & 509 & 2.2 & 64.9 & 12.5 & \\
\hline Total & Computed: TN/TP & 369 & 2.0 & 36.8 & 11.6 & \\
\hline \multicolumn{7}{|l|}{ Estuarine environment } \\
\hline Salinity & & 507 & 0.1 & 33.5 & 23.2 & 13.6 \\
\hline Chlorophyll-a $\left(\mu \mathrm{g}^{-1}\right)$ & & 510 & 1.0 & 52.2 & 5.2 & 9.8 \\
\hline SPM $\left(\mathrm{mg} \mathrm{l}^{-1}\right)$ & & 511 & 2.0 & 703 & 39.0 & 7.8 \\
\hline
\end{tabular}

DIP year ${ }^{-1}$, and not significantly different from zero $(P=$ 0.60 and 0.86 , respectively). Therefore, stocks of dissolved inorganic nutrients have not accumulated in the estuary over the past decade. This test also showed no significant trends of annualized bay-wide mean chl-a $\left(-0.08 \mu \mathrm{g} \mathrm{l}^{-1}\right.$ year $\left.^{-1}, P=0.11\right)$ or SPM concentration (0.27 $\mathrm{mg} \mathrm{l}^{-1}$ year $\left.^{-1}, P=0.48\right)$. These results imply no accumulation of nutrients associated with phytoplankton $\left(\mathrm{N}_{\text {phyt }}\right)$ or suspended sediments $\left(\mathrm{N}_{\text {sed }}\right)$ over the past decade. The observational record is too short to determine if dissolved organic $\mathrm{N}$ or $\mathrm{P}$ have changed over the past decade, but the available data indicate that $\mathrm{N}$ and $\mathrm{P}$ are not accumulating in San Francisco Bay waters (Table 3). Therefore, nutrient inputs to the Bay appear to be balanced by internal losses and export.

Internal Losses Particle sinking and burial can be an important loss of $\mathrm{N}$ and $\mathrm{P}$ in depositional regions of estuaries (e.g., Boynton et al. 1995; Eyre et al. 2016). San Francisco Bay has had an exceptional history of alternating eras of sediment accretion and erosion, but it is now in an era of sediment loss. This has been learned from comparisons of bathymetric surveys to measure changes in morphometry and, thus, sediment gain or loss between different eras (e.g., Jaffe et al. 1998). These studies show that San 
Table 3 Estimated daily N and P budget terms for San Francisco Bay. Values in italics are from direct measurements. Negative exports are transport into San Francisco Bay

\begin{tabular}{|c|c|c|c|}
\hline Nitrogen & Tons $\mathrm{N}$ day ${ }^{-1}$ & Phosphorus & Tons $\mathrm{P}$ day $^{-1}$ \\
\hline Input $^{1}$ & $>82.9$ & Input $^{1}$ & $>8.1$ \\
\hline DIN accumulation $^{2}$ & 0.0 & DIP accumulation ${ }^{2}$ & 0.0 \\
\hline $\mathrm{N}_{\text {phyt }}$ accumulation ${ }^{2}$ & 0.0 & $\mathrm{P}_{\text {phyt }}$ accumulation ${ }^{2}$ & 0.0 \\
\hline $\mathrm{N}_{\text {sed }}$ accumulation ${ }^{2}$ & 0.0 & $\mathrm{P}_{\text {sed }}$ accumulation ${ }^{2}$ & 0.0 \\
\hline Denitrification $^{3}$ & 38.7 & & \\
\hline $\mathrm{N}_{\text {phyt }}$ export ${ }^{4}$ & -6.3 to 1.1 & $\mathrm{P}_{\text {phyt }}$ export $^{4}$ & -0.6 to 0.1 \\
\hline $\mathrm{N}_{\text {sed }}$ export $^{5}$ & 9.3 & $\mathrm{P}_{\text {sed }}$ export $^{5}$ & 5.1 \\
\hline $\mathrm{N}_{\text {fish }}$ emigration ${ }^{6}$ & $>3.7$ & $\mathrm{P}_{\text {fish }}$ emigration ${ }^{6}$ & $>1.1$ \\
\hline Export DIN+DON $^{7}$ & $>30.1$ & Export DIP+DOP ${ }^{7}$ & $>1.8$ \\
\hline
\end{tabular}

${ }^{1}$ Estimated from Novick and Senn (2014): $89 \%$ of TN input is DIN; 78\% of TP input is DIP

${ }^{2}$ Based on Baywide trends of DIN, DIP, chl-a and SPM over the decade 2009-2018

${ }^{3}$ From Smith and Hollibaugh (2006)

${ }^{4}$ From Martin et al. (2007); positive fluxes are exports to the ocean

${ }^{5}$ From the sediment budget of a normal water year (Schoellhamer et al. 2005)

${ }^{6}$ From Deegan (1993)

${ }^{7}$ Residual $=$ input minus maximum value of summed loss terms

Francisco Bay system has lost $7 \times 10^{6} \mathrm{~m}^{3}$ year $^{-1}$ of sediment in recent decades as a consequence of reduced sediment supply and increased dredging and export to the ocean and wetlands. On this basis, we infer that $\mathrm{N}$ and $\mathrm{P}$ are not currently being lost to burial in San Francisco Bay, although nutrients must have accumulated in sediments during earlier periods of deposition.

Denitrification is a second important loss of $\mathrm{N}$ from estuaries, but rates have not been measured in San Francisco Bay. However, Smith and Hollibaugh (2006) used measurements of flow, salinity, and nutrients to infer rates of biogeochemical transformations in North and South Bay. Differences between modeled and measured changes in DIN were interpreted as rates of net denitrification, i.e. the difference between $\mathrm{N}$ fixation and denitrification. The median calculated rate of net denitrification was $1757 \times 10^{3} \mathrm{~mol} \mathrm{~N}$ day $^{-1}$ (Table 9 in Smith and Hollibaugh (2006)). If this areal rate applies also to Central Bay, then net denitrification across the entire San Francisco Bay system is estimated as $38.7 \mathrm{t} \mathrm{N}$ day $^{-1}$ (Table 3 ).

Loss to Export Lastly, we consider nutrient losses to the Pacific Ocean using a range of measurement types. Martin et al. (2007) directly measured Bay-ocean fluxes of phytoplankton biomass during three seasons using cross-sectional profiling of currents and chl-a concentrations at the Golden Gate. Net export over complete tidal cycles ranged from $7718 \mathrm{mg}$ chl-a $\mathrm{s}^{-1}$ (out of San Francisco Bay) during spring to $-1285 \mathrm{mg}$ chl-a s ${ }^{-1}$ (into San Francisco Bay) during the summer upwelling season. From these, and our measured PN/chl-a and PP/ chl-a ratios (Table 2), we computed $\mathrm{N}_{\text {phyt }}$ and $\mathrm{P}_{\text {phyt }}$ exports ranging from -6.3 to $+1.1 \mathrm{t} \mathrm{N}^{-1}{ }^{-1}$, and -0.6 to + $0.1 \mathrm{t} \mathrm{P} \mathrm{day}^{-1}$, respectively (Table 3 ). Although the measurements are limited in number, they provide evidence that bayocean water exchange can be an important process of both exporting and importing $\mathrm{N}$ and $\mathrm{P}$ contained in phytoplankton biomass. We estimated export of sediment-associated $\mathrm{N}$ and $\mathrm{P}$ from a sediment budget (Schoellhamer et al. 2005) built from measured inputs to San Francisco Bay and changes in storage from the bathymetric surveys cited above. The sediment budget for a normal water year indicated loss of $2.4 \times 10^{6} \mathrm{t}$ of sediment per year. We multiplied this sediment loss by the ratios of $\mathrm{PN} / \mathrm{SPM}$ and $\mathrm{PP} / \mathrm{SPM}$ derived from our data (Table 2) to compute daily export losses of $9.3 \mathrm{t} \mathrm{N}_{\text {sed }}$ and $5.1 \mathrm{tP}_{\text {sed }}$ (Table 3).

Another process of nutrient export could be loss of biomass to harvest or emigration of fish or shellfish. Large-scale commercial fishing and aquaculture in San Francisco Bay ended decades ago, so we presume this process of nutrient export is unimportant now. However, San Francisco Bay is a spawning habitat for marine fishes and rearing habitat for early-stage fish and crustaceans that mature in the Bay and then emigrate to the Pacific Ocean. Export of nutrients by fish migration is rarely measured in estuaries, but Deegan (1993) demonstrated that this process can be of comparable magnitude to nutrient export by water exchange. Her study focused on Gulf menhaden (Brevoortia patronus) that immigrates into estuaries as larvae and emigrates to coastal waters as juveniles. Emigration of menhaden from Fourleague Bay LA exported $3.1 \mathrm{~g} \mathrm{~N} \mathrm{~m}^{-2}$ year $^{-1}$ and $0.9 \mathrm{~g} \mathrm{P} \mathrm{m}^{-2}$ year $^{-1}$. These areal rates, applied to San Francisco Bay, would export $3.7 \mathrm{t}$ of $\mathrm{N}$ and $1.1 \mathrm{t}$ of $\mathrm{P}$ per day. We included these values in Table 3 simply as placeholders to recognize that biotic transport could be an important, but unmeasured, process of nutrient export from San Francisco Bay. The actual losses could be larger, given the high abundances and multiple species of marine fish and crustaceans that grow in San Francisco Bay and emigrate to the coastal ocean, such as Crangon shrimp, Dungeness crab (Cancer magister), and English sole (Parophrys vetulus) (Raimonet and Cloern 2016).

Nutrient Budgets The process rates compiled here provide the first estimates of nitrogen and phosphorus budgets for San Francisco Bay. Most terms were derived indirectly and all have large uncertainty, but one important conclusion is grounded in a rigorous data set: DIN and DIP have not accumulated over the past decade, so their inputs must be balanced by internal losses and exports. The current era of sediment loss sets San Francisco Bay apart from many other estuaries, such as Chesapeake Bay and its tributary estuaries where sediment deposition of PN buries $28-53 \%$ of total nitrogen inputs and PP deposition buries over $100 \%$ of total phosphorus inputs (Boynton et al. 1995). The well-documented net erosion of 
sediments in San Francisco Bay implies that nutrient burial is not an important internal loss process from this estuary now. However, losses of sediment to the coastal ocean and dredging imply that export of sediment-bound nutrients is an important component of the $\mathrm{N}$, and particularly the P, budget (Table 3 ). The $\mathrm{P}$ budget has no internal losses, so phosphorus inputs and exports are balanced. Phosphorus exports include, in descending order, $\mathrm{P}_{\text {sed }}$ and DIP+DOP export by bay-ocean mixing, and export of $\mathrm{P}$ in biota. The two important loss terms in the $\mathrm{N}$ budget are denitrification and DIN+DON export. The large uncertainties of these two processes preclude assessment of their relative importance. Export of sediment-bound $\mathrm{N}$ accounts for a loss of about $10 \%$ of $\mathrm{N}$ input, and losses to biotic emigration could be of similar magnitude.

Recycling The budget above is a static accounting of inputs and outputs, but it provides little information about the cycling of nutrients once they enter San Francisco Bay. Nitrogen and phosphorus are reactive, essential elements of life, and their dissolved inorganic forms are rapidly assimilated into microbial biomass. We estimated the mass of $\mathrm{N}$ and $\mathrm{P}$ assimilated by microalgae from their bay-wide net primary productivity of $1.75 \times$ $10^{8}$ t $C$ year $^{-1}$ (Jassby et al. 1993). The molar ratios $\mathrm{C} / \mathrm{N} / \mathrm{P}$ in microalgae are variable, but mean ratios of phytoplankton grown in nutrient-rich cultures are $\mathrm{C} / \mathrm{N}=7.7$ and $\mathrm{C} / \mathrm{P}=75$ (Geider and La Roche 2002). Therefore, this bay-wide carbon fixation rate implies that microalgae assimilate $73 \mathrm{t}$ of $\mathrm{N}$ and $16.5 \mathrm{t}$ of $\mathrm{P}$ per day, equal to $100 \%$ of the daily DIN input and $260 \%$ of DIP input (Table 1). About $70 \%$ of microalgal production is contributed by phytoplankton (Jassby et al. 1993), so this community plays a central role in nutrient cycling by transforming DIN and DIP into algal biomass. That biomass does not accumulate in the estuary (Table 3) because it is rapidly consumed and metabolized, releasing organic forms of $\mathrm{N}$ and $\mathrm{P}$. While phytoplankton assimilation has no net effect on the annual $\mathrm{N}$ or $\mathrm{P}$ budgets of San Francisco Bay, it is a key entry point into a biotic recycling system in which nutrients are assimilated and metabolized multiple times (Boynton et al. 2008). This recycling system, which also includes potentially large uptake by heterotrophic bacteria (Kirchman 1994), does have a net effect on the composition of nitrogen compounds by transforming DIN into particulate and organic forms. This is evidenced by the smaller ratio of DIN:TN in San Francisco Bay (mean 61\%, Table 2) compared to that in wastewater inputs to San Francisco Bay of $89 \%$ (Novick and Senn 2014).
Part 2: Management Implications and Actions

The information contained in our assessment of nutrient status has raised concern about nutrient enrichment of San Francisco Bay to a level that did not exist a decade ago. Here, we present the rationale for this growing concern, and then describe responses to it by the management and scientific communities.

\section{Three Reasons for Concern}

Risks of Nutrient Enrichment In the early 1980s, Scott Nixon and his colleagues used mesocosm experiments to learn how Narragansett Bay might respond to elevated rates of nitrogen loading. Results showed that a 32-fold increase in $\mathrm{N}$ loading led to increases of mean chl-a from 2 to $18 \mu \mathrm{g} \mathrm{l}^{-1}$ and annual primary production from 80 to $320 \mathrm{~g} \mathrm{C} \mathrm{m}^{-2}$ (Nixon et al. 2001). This now-classic experiment was among the first to measure estuarine phytoplankton responses to nutrient enrichment. Comparisons across many estuarine-coastal ecosystems have since established strong associations between phytoplankton biomass (chl-a) and TN and TP concentrations (Smith 2006). At some levels, the increased phytoplankton production from nutrient enrichment generates responses we would judge as positive, including amplified production of species we harvest for food (Nixon and Buckley 2002). However, production of harvestable species begins to decrease after nutrient supplies reach a critical loading rate (e.g., Josefson and Rasmussen 2000). Once that threshold is exceeded, a syndrome of responses follows that we judge as negative. The syndrome includes elevated rates of ecosystem metabolism and oxygen consumption (Caffrey 2004).

The link between nutrient enrichment and ecosystem metabolism underlies the expansion of hypoxia and anoxic dead zones across the world's coastal zones (Diaz and Rosenberg 2008). Hypoxia is a physiological stress to fish and shellfish and constricts their habitat; anoxia leads to fish kills (Paerl et al. 1998), and loss of oxygen has feedback effects on the eutrophication syndrome by suppressing nitrificationdenitrification and releasing sediment-bound phosphate (Kemp et al. 2009). Elevated metabolism leads to increased $\mathrm{CO}_{2}$ production and acidification as another threat to shellfish and finfish (Wallace et al. 2014). Other manifestations of nutrient enrichment include loss of eelgrasses (Hauxwell et al. 2003) and saltmarshes (Deegan et al. 2012), and promotion of harmful algal blooms with growing economic costs and risks to health of humans, fish, and sea birds (Anderson 2009). As a consequence of these broad-ranging disturbances by nutrient enrichment, coastal eutrophication is an environmental problem of global significance.

By world standards, San Francisco Bay has high nutrient loadings (Fig. 3) and high concentrations of nitrogen and phosphorus (Table 2), primarily from municipal wastewater. Nutrient enrichment at this level sets the 
potential for degradation of water and habitat quality that has occurred in other US estuaries and coastal waters such as Chesapeake Bay (Kemp et al. 2005), Long Island Sound (O'Shea and Brosnan 2000), Neuse River Estuary (Paerl et al. 1998), Elkhorn Slough (Hughes et al. 2011), Tampa Bay in the 1970s (Greening et al. 2014), and the Mississippi River plume in the Gulf of Mexico (Rabalais et al. 2002).

Potential Warning Signs Although San Francisco Bay has not been degraded by the hypoxia/anoxia that develops in these other enriched estuaries, signals of nutrient-enrichment effects are present in our observational records. Although the open waters of San Francisco Bay are well oxygenated (Table 2), tidal sloughs and ponds connected to the Lower South Bay produce high phytoplankton biomass (chl-a $>50 \mu \mathrm{g} \mathrm{l}^{-1}$ ) and have diel cycles of dissolved oxygen that oscillate between near-anoxia and supersaturation (Thebault et al. 2008). Second, although San Francisco Bay does not have recurrent high-biomass algal blooms, events of extremely high biomass accumulation have developed over large regions of the bay. Spring blooms in 1998 reached chl-a concentrations exceeding $100 \mu \mathrm{g} \mathrm{l}^{-1}$ from Lower South Bay to San Pablo Bay. This was a strong El Niño year of high runoff and unusually persistent salinity stratification, illustrating one mechanism through which hydroclimatic variability regulates the efficiency of biomass production. Our sampling also captured a largescale red tide event in 2004 when surface chl-a concentrations in South and Central Bay exceeded $100 \mu \mathrm{g} \mathrm{l}^{-1}$ (Cloern et al. 2005). That bloom occurred when thermal stratification was set up by a heat wave when an anomalous high-pressure system developed along the US west coast. That bloom was dominated by species that develop harmful algal blooms (HABs) in other estuaries-Akashiwo sanguinea, Heterocapsa rotundata, and Prorocentrum micans (Cloern et al. 2005) These examples illustrate that the high potential for biomass production in San Francisco Bay can be fully realized under some hydroclimatic conditions.

More recent observations provide further evidence of water quality changes that might be tied to nutrient enrichment. Visible HABs are not regular occurrences in San Francisco Bay, but its phytoplankton community includes three toxinproducing taxa: the domoic-acid producing diatom Pseudonitzschia, saxitoxin-producing dinoflagellate Alexandrium sp., and okadaic-acid producing dinoflagellate Dinophysis sp. (Sutula et al. 2017). These three toxins co-occur in San Francisco Bay along with microcystins produced by the freshwater cyanobacteria Microcystis (Peacock et al. 2018). All four toxins have been found in water and in California mussels (Mytilus californianus) grown in San Francisco Bay, with microcystins detected in 56\%, domoic acid in $98 \%$, paralytic shellfish toxins (including saxitoxin) in 59\%, and Dinophysis shellfish toxins in $71 \%$ of samples. The unexpected co-occurrence of four classes of toxins produced by both marine and freshwater taxa leaves an open question about their cumulative effects as risks to the health of San Francisco Bay biota and human consumers.

Nutrient Management in a Changing World Over the past three decades, several regional and national programs have been implemented to reverse the effects of nutrient pollution by reducing $\mathrm{N}$ and $\mathrm{P}$ inputs to estuarine-coastal ecosystems. Some have been successful, and perhaps the most notable US example is recovery of Tampa Bay from the severe ecosystem disturbances manifested in the 1970s (Greening et al. 2014). More commonly, however, outcomes of nutrient reductions have differed from the expectation that estuaries will re-trace their trajectories of impairment and return to a pre-enrichment state. Duarte et al. (2009) examined chl-a records in four estuarine-coastal ecosystems that had early (1970s1980s) trends of significant nutrient increase followed by trends of significant nutrient decrease after regulatory controls were enacted. In each case, annual mean chl-a was higher at the end of the record than at the beginning, and the chl-a trajectories during the era of nutrient reduction were complex, convoluted departures from expectations. The authors attributed these unexpected responses to "shifting baselines"-i.e., concurrent changes in environmental factors that regulate conversion of nutrients into biomass, such as changes in food web structures and climate. A subsequent study (Carstensen et al. 2011) found highly variable phytoplankton-nutrient relationships across 28 coastal ecosystems, and that the production of phytoplankton biomass per unit nitrogen nearly doubled over the past 3-4 decades across all regions. This is compelling evidence that the efficiency of phytoplankton nutrient utilization can change over periods of decades in synchrony with global changes such as increasing temperature and $\mathrm{CO}_{2}$ concentrations, overfishing, and harvest of filter feeders (Carstensen et al. 2011).

Our observations captured a baseline shift in San Francisco Bay after 2000, when summer (June-September) chl-a concentrations began to increase in South Bay (Fig. 6). This chl-a increase was attributed to loss of bivalves and their filterfeeding control of phytoplankton biomass when biological communities were restructured following a 1999 shift in climate forcing of the Northeast Pacific (Cloern et al. 2010). The Pettit change-point test (wql function pett) identified a significant $\left(P<10^{-5}\right)$ change in the summer chl-a series after 2000 . The size effect of this change (median of all differences between 1978-2000 and 2001-2018 measurements) was $3.2 \mu \mathrm{g} 1^{-1}$. A chl-a shift of this magnitude implies two important changes: (1) increased efficiency of $\mathrm{N}$ and $\mathrm{P}$ utilization (Fig. 6); and (2) increased primary production that, since 
Fig. 6 Changes from 1978 to 2018 in the median values of summer (June-September) surface chl-a, $\mathrm{N}$ utilization efficiency, and $\mathrm{P}$ utilization efficiency measured from stations 21 to 32 (Fig. 1)
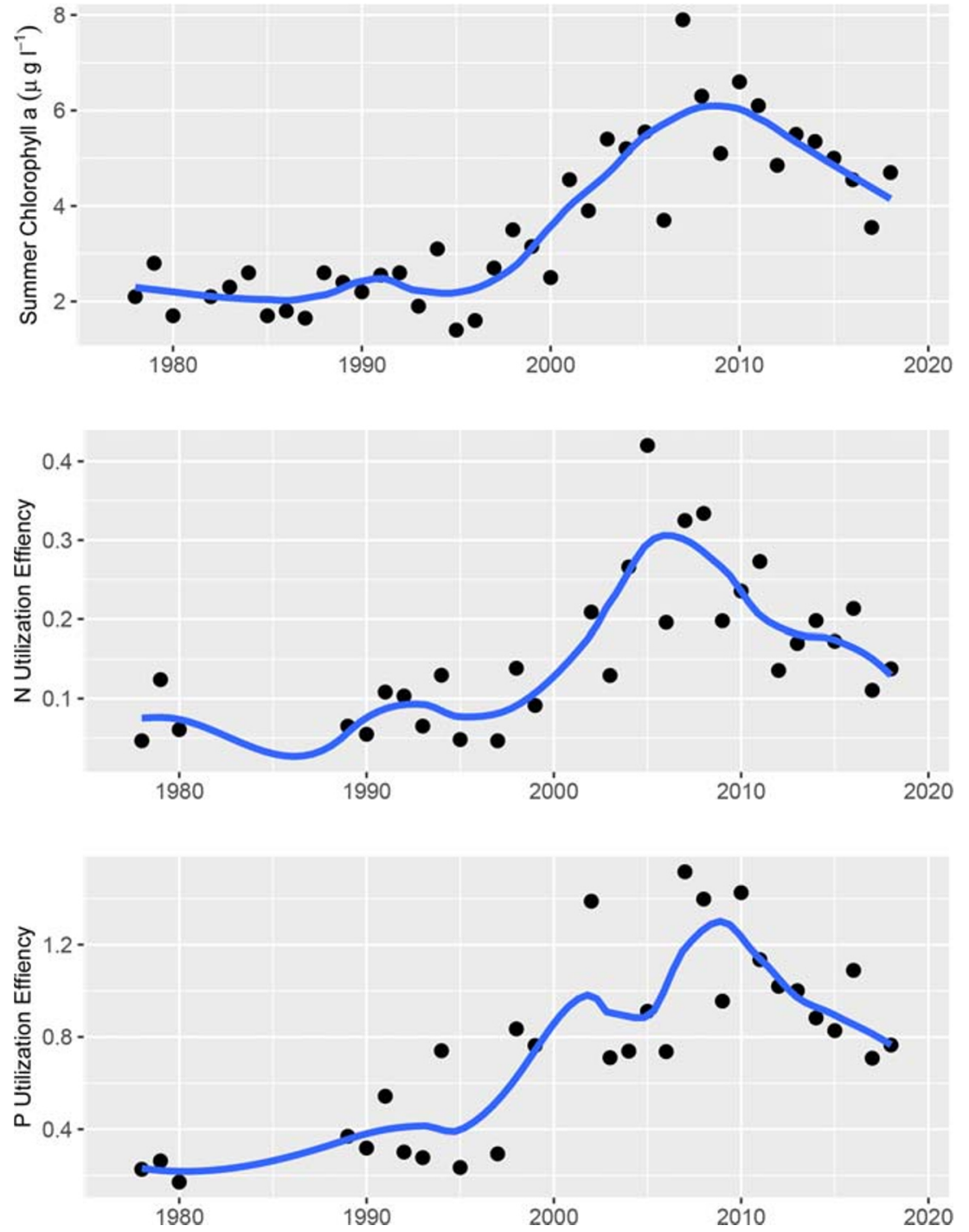

2000, has twice exceed $300 \mathrm{~g} \mathrm{C} \mathrm{m}^{-2}$ year $^{-1}$, signaling a possible transition from a mesotrophic to a eutrophic estuary (Nixon 1995). This example of a baseline shift illustrates the dynamic nature of estuarine ecosystems where processes regulating algal production can change, sometimes abruptly and unexpectedly.

\section{Responses to Concern about Nutrient Enrichment}

Regulatory Responses The development of hypoxia in peripheral habitats, increase of summer chl-a after 2000, presence of HAB-forming phytoplankton taxa, and multiple algal toxins in biota, have generated concern that San Francisco Bay has reached a tipping point of nutrient impairment. If this is the case, advanced wastewater treatment may now be required to remove $\mathrm{N}$ and $\mathrm{P}$ from POTW effluents, as it has in other estuaries. As a response to this concern, the San Francisco Bay Regional Water Quality Control Board issued an interim, 5-year discharge permit to 37 POTWs. This permit "sets forth a regional framework to facilitate collaboration on studies that will inform future management decisions and regulatory strategies" (BACWA 2018). The permit includes provisions to: (1) evaluate the processes required and their costs to reduce nutrient discharges through upgrades of wastewater treatment; and (2) support targeted studies to better understand potential and realized effects of nutrient enrichment so that water quality objectives can be established for San Francisco Bay.

The first task has been completed by the Bay Area Clean Water Agencies (BACWA), a joint powers agency representing the dischargers. Its evaluation compared the costs of treatment upgrades at two levels: one based on optimization of conventional treatments that would remove $57 \%$ of TN and $59 \%$ of TP in effluents, and a second that would include new processes (e.g., denitrification, coagulation) to remove $82 \%$ and $88 \%$ of effluent TN and TP, respectively. The current cost estimates of these upgrades are US \$9.4 billion for the first level, and US \$12.4 billion for the higher level of nutrient removal (BACWA 2018). These costs are substantial, and 
they motivated the second provision of targeted studies that was realized through creation of a Nutrient Management Strategy (NMS) - a multi-stakeholder collaboration charged with developing a "coherent nutrient science and management strategy for the Bay" (https://sfbaynutrients.sfei.org/).

Responses of the Scientific Community Based on our assessment of the nutrient status of San Francisco Bay, policymakers now ask for guidance as they face the essential question: What is the appropriate protective policy for this estuary? Targeted research, funded by the dischargers and directed by the NMS, is in process or planned to address three challenges common to all nutrient management programs:

1. Numeric targets: Regulatory policies to protect coastal waters from the eutrophication syndrome are implemented using targets expressed as numerical indicators of the direct effects of nutrient enrichment such as increased algal production or biomass, and indirect effects such as loss of oxygen or biological diversity (e.g., Ferreira et al. 2011). Establishment of numeric targets was a key to success for the Tampa Bay Estuary Program in reversing the effects of nutrient enrichment (Greening et al. 2014). Numeric targets have not yet been established to guide nutrient management of San Francisco Bay. As a first step, Sutula et al. (2017) analyzed two decades of observational data to determine if chl-a can be used as one indicator of adverse effects of nutrient enrichment in San Francisco Bay, as it has in many other estuaries. Regression analyses showed positive relationships between chl-a concentration and: (1) abundances of toxigenic phytoplankton taxa (Alexandrium, Dinophysis, Karlodinium, Pseudo-nitzschia), and (2) concentrations of algal toxins. Conditional probability analysis identified a chl-a limit of $13 \mu \mathrm{g} \mathrm{l}^{-1}$ as a "protective" threshold below which probabilities are small for exceeding alert levels of algal abundances or toxins. They also found lowest summer DO concentrations in years of highest seasonal-mean (February-September) chl-a, and identified a seasonal-mean chl-a concentration of 13$16 \mu \mathrm{g} \mathrm{l}^{-1}$ as a limit beyond which the state's Water Quality Criterion for DO might not be met. These targets were developed to identify chl-a levels that "constitute tipping points of phytoplankton biomass beyond which water quality will become degraded, requiring significant nutrient reductions" (Sutula et al. 2017).

In today's hydroclimatic setting, seasonal-mean chl-a concentrations in San Francisco Bay are usually less than the proposed target of $13 \mu \mathrm{g} 1^{-1}$, even though the nutrient-based potential for biomass accumulation is much higher. However, as we have learned from studies of other estuaries, phytoplankton production efficiency can change over time. A critical uncertainty is long-term persistence of the physical attributes of San Francisco Bay that constrain production efficiency - turbulent mixing that breaks down stratification, and high turbidity that limits light availability. Intermittent stratification is a key feature that sets San Francisco Bay apart from Chesapeake Bay where stratification and hypoxia persist during summer (Kemp et al. 2005). Therefore, policymakers ask if there are plausible scenarios of altered freshwater inputs, warming of the surface layer, and rising water level such that regions of San Francisco Bay could become stratified long enough to promote large blooms and for bottom waters to lose their oxygen content. These scenarios can be developed from California's Fourth Climate Change Assessment (Ackerly et al. 2018) and its projections of: regional warming of up to $2.4{ }^{\circ} \mathrm{C}$ by mid-century; more frequent, larger magnitude and longer duration heat waves (up to 40 more extreme heat days per year by 2050); increased magnitude of high precipitation events; and sea level rise potentially reaching $3 \mathrm{~m}$ by 2100 . Equally important is the future trajectory of water clarity that has increased over recent decades because of altered wind patterns and reduced sediment supplies to the estuary (Bever et al. 2018). Several 3D models of hydrodynamics and sediment transport have been calibrated and validated for San Francisco Bay (e.g., Elmilady et al. 2018; Bever and MacWilliams 2013). These kinds of physical models can be coupled with nutrient-phytoplankton models to assess the likelihood that chl-a levels will regularly exceed numeric targets in a future climate. These scenarios can also provide policymakers a basis for deciding if regulatory policies should be adapted to current or to future hydroclimatic conditions.

2. Nutrients and algal toxins: A second key uncertainty is the strength of coupling between nutrient enrichment and algal toxins in San Francisco Bay. We know with certainty that the phytoplankton community includes species that form HABs elsewhere, and that multiple algal toxins are measured at levels that pose health risks to estuarine biota and humans (Peacock et al. 2018). However, there is uncertainty about the extent to which nutrient reductions can reduce these HAB risks in San Francisco Bay. This uncertainty arises in part from the connections of San Francisco Bay to (1) an inland delta and urban reservoirs that have recurrent Microcystis blooms and high concentrations of microcystin (Lehman et al. 2013), and (2) a coastal upwelling system that develops Pseudo-nitzschia blooms that have led to fisheries closures and mortalities of seabirds and marine mammals in the coastal Pacific (McCabe et al. 2016).

Deeper understanding of the nutrient-HAB linkage and its potential for management will require investments in new research directions to answer fundamental questions. Are HAB-forming diatoms and dinoflagellates and their toxins produced primarily in San Francisco Bay, or in the coastal ocean and transported into San Francisco Bay? Is the export of N and P from San Francisco Bay an important source of nutrients supporting HABs in the adjacent coastal Pacific, as it is in the nearshore Southern California Bight (Howard et al. 2014)? What roles do nutrients play in regulating toxin production? What environmental factors 
trigger population growth and toxin synthesis of HAB taxa? What is the source of microcystin and its pathway for movement into the Bay? Will reductions of microcystin require active nutrient management of surrounding inland waters, while reductions of marine algal toxins require reduction of wastewater nutrient inputs to the Bay? The global HAB community has recently provided guidance about research approaches for answering these kinds of questions (Wells et al. 2019). The stakes are high because if the chronic presence of algal toxins in San Francisco Bay is a consequence of nutrient enrichment, then this would be compelling evidence of current impairment and a need for regulatory actions to reduce nutrient loadings.

3. Toward a nutrient management plan: A third common challenge of nutrient management is to determine the magnitude of nutrient load reduction required to meet numeric targets, such as chl-a thresholds. Loading goals are usually developed using models that range from simple to complex. The management target for Chesapeake Bay is a $43 \%$ reduction of both N and P loading from 1985 levels (Boesch 2019), and these targets were set using simulations with a coupled airshed-watershed-estuarine model (Linker et al. 2013). Nutrient management of San Francisco Bay will require a similar model to project water-quality and ecological responses to different levels of $\mathrm{N}$ and $\mathrm{P}$ load reduction. These projections are best viewed as a starting place because responses to nutrient load reduction often deviate, sometimes substantially, from the model projections used to set loading targets. Realized responses to nutrient reduction have "variously been effective, ineffective, recalcitrant and sometimes surprising" (Boesch 2019). Ineffective, recalcitrant and surprising responses to action plans imply that strategies of nutrient management require adaptability (e.g., changing targets), patience (over decades), and ongoing monitoring to capture and understand surprises as they unfold.

The intergovernmental commitments to reduce nutrient inputs to Chesapeake Bay have been sustained for over 35 years, with measured progress toward nutrient reductions but slower progress toward the rehabilitation goals. The slow pace of progress, relative to expectations, reflects the complexity of the coastal eutrophication problem. One example of complexity arises from the large stocks of nitrogen and phosphorus that have accumulated over decades in bottom sediments. This "internal source" of nutrients can continue to fuel phytoplankton production as external nutrient loadings are reduced, leading to lagged (recalcitrant) responses to regulatory actions. Our measurements of the $\mathrm{N}$ and P content of sediments in San Francisco Bay (1.4 mg N and $0.78 \mathrm{mg} \mathrm{P} \mathrm{g}^{-1}$ sediment) allow us to estimate the size of those stocks. Assuming that the active sediment layer is 15$\mathrm{cm}$ deep (Davis 2004) and sediment density is $2.7 \mathrm{~g} \mathrm{~cm}^{-3}$ (Fuller et al. 1999), these nutrient/sediment ratios imply stocks of $2.5 \times 10^{5} \mathrm{t}$ of $\mathrm{N}$ and $1.4 \times 10^{5} \mathrm{t} \mathrm{P}$ in the bottom sediments of San Francisco Bay. These are equivalent to 8.4 years of today's external $\mathrm{N}$ loading and 4.7 years of $\mathrm{P}$ loading. Additional stocks of $\mathrm{N}$ and $\mathrm{P}$ are contained in the sediment pore waters. Coupled water-column sediment models that account for these internal sources can project rates of DIN and DIP decrease after nutrient reductions begin. For example, model simulations by Soetaert and Middelburg (2009) indicate that a 50\% reduction of external $\mathrm{N}$ loading can ultimately reduce DIN concentrations by more than $50 \%$, but the process develops over a period of 1-2 decades as the internal source is gradually depleted. Models can be useful for setting targets, but also for judging the time scale over which those targets can be met.

The learning experiences from successes and failures at managing nutrient pollution along world's coastlines provide a collective wisdom about how to solve this complex and challenging problem. In his review of those experiences, Boesch (2019) encapsulates that wisdom as guidance for resource managers of San Francisco Bay and other coastal ecosystems: "Outcomes must be measured and strategies appropriately adjusted through: sustained monitoring of essential indicators and processes, the use of multiple models, truly adaptive management, and cautious interventions within the coastal ecosystem. The changing climate must be taken into account by reassessing achievable future conditions and seeking alternatives for mitigating and adapting to climate change that also reduce nutrient loads."

Acknowledgments Any use of trade, firm, or product names in this publication is for descriptive purposes only and does not imply endorsement by the US Government. This research was supported by the USGS Water Mission Area, USGS Ecosystems Mission Area, and the Regional Monitoring Program of the San Francisco Estuary Institute. We appreciate the thoughtful comments and suggestions from reviewers that strengthened this paper.

Open Access This article is licensed under a Creative Commons Attribution 4.0 International License, which permits use, sharing, adaptation, distribution and reproduction in any medium or format, as long as you give appropriate credit to the original author(s) and the source, provide a link to the Creative Commons licence, and indicate if changes were made. The images or other third party material in this article are included in the article's Creative Commons licence, unless indicated otherwise in a credit line to the material. If material is not included in the article's Creative Commons licence and your intended use is not permitted by statutory regulation or exceeds the permitted use, you will need to obtain permission directly from the copyright holder. To view a copy of this licence, visit http://creativecommons.org/licenses/by/4.0/.

\section{References}

Ackerly, D., A. Jones, M. Stacey, and B. Riordan. 2018. Francisco Bay Area summary report. California's Fourth Climate Change Assessment. Publication number: CCCA4-SUM-2018-005. Available at https://www.energy.ca.gov/sites/default/files/2019-07/ 
Re g \% 20 Re port - \% 20 S U M - C C C A $4-2018-005 \%$ 20SanFranciscoBayArea.pdf. Accessed 26 March 2020.

Anderson, D.M. 2009. Approaches to monitoring, control and management of harmful algal blooms (HABs). Ocean \& Coastal Management 52 (7): 342. https://doi.org/10.1016/j.ocecoaman. 2009.04.006.

Arar, E., and G. Collins. 1997. In-vitro determination of chlorophyll a and pheophytin a in marine and freshwater algae by fluorescence. US Environmental Protection Agency, Method EPA 445: 1-23.

BACWA. 2018. Potential nutrient reduction by treatment optimization, sidestream treatment, treatment upgrades, and other means. Bay Area Clean Water Agencies Final Report June 22, 2018. Available at https://bacwa.org/wp-content/uploads/2018/06/BACWA_Final_ Nutrient Reduction Report.pdf. Accessed 26 March 2020.

Bever, AJ., and M.L. MacWilliams. 2013. Simulating sediment transport processes in San Pablo Bay using coupled hydrodynamic, wave, and sediment transport models. Marine Geology 345: 235-253. https:// doi.org/10.1016/j.margeo.2013.06.012.

Bever, A.J., M.L. MacWilliams, and D.K. Fullerton. 2018. Influence of an observed decadal decline in wind speed on turbidity in the San Francisco Estuary. Estuaries and Coasts 41 (7):1943-1967. https:// doi.org/10.1007/s12237-018-0403-x

Boesch, D.F. 2019. Barriers and bridges in abating coastal eutrophication. Frontiers in Marine Science 6. https://doi.org/10.3389/fmars.2019. 00123.

Bojinski, S., M.Verstraete, T.C. Peterson, C. Richter, A. Simmons, and M. Zemp. 2014. The concept of essential climate variables in support of climate research, applications, and policy. Bulletin of the American Meteorological Society 95 (9): 1431-1443. https://doi.org/10.1175/ bams-d-13-00047.1.

Boynton, W.R., J.H. Garber, R. Summers, and W.M. Kemp. 1995. Inputs, transformations, and transport of nitrogen and phosphorus in Chesapeake Bay and selected tributaries. Estuaries 18 (1B): 285314.

Boynton, W.R., L. Murray, J.D. Hagy, C. Stokes, and W.M. Kemp. 1996. A comparative analysis of eutrophication patterns in a temperate coastal lagoon. Estuaries 19 (2): 408-421.

Boynton, W.R., J.D. Hagy, J.C. Cornwell, W.M. Kemp, S.M. Greene, M.S. Owens, J.E. Baker, and R.K. Larsen. 2008. Nutrient budgets and management actions in the Patuxent River Estuary, Maryland. Estuaries and Coasts 31 (4): 623-651. https://doi.org/10.1007/ s12237-008-9052-9.

Bronk, D.A., J.H. See, P. Bradley, and L. Killberg. 2007. DON as a source of bioavailable nitrogen for phytoplankton. Biogeosciences 4 (3): 283-296.

Caffrey, J.M. 2004. Factors controlling net ecosystem metabolism in US estuaries. Estuaries 27 (1): 90-101.

Carstensen, J., M. Sanchez-Camacho, C.M. Duarte, D. Krause-Jensen, and N. Marba. 2011. Connecting the dots: Responses of coastal ecosystems to changing nutrient concentrations. Environmental Science \& Technology 45 (21): 9122-9132. https://doi.org/10. 1021/es202351y.

Cloern, J.E. 1996. Phytoplankton bloom dynamics in coastal ecosystems: A review with some general lessons from sustained investigation of San Francisco Bay, California. Reviews of Geophysics 34 (2): 127 168

Cloern, James E. 2017. Why large cells dominate estuarine phytoplankton. Limnology and Oceanography 62 (S1): S392-S409. https://doi. org/10.1002/lno.10749.

Cloern, J.E., and A.D. Jassby. 2008. Complex seasonal patterns of primary producers at the land-sea interface. Ecology Letters 11 (12): 1294-1303. https://doi.org/10.1111/j.1461-0248.2008.01244.x.

Cloern, J.E., and T.S. Schraga. 2016. USGS measurements of water quality in San Francisco Bay (CA), 1969-2015: U. S. Geological Survey data release, https://doi.org/10.5066/F7TQ5ZPR
Cloern, J.E., T.S. Schraga, C.B. Lopez, N. Knowles, R.G. Labiosa, and R. Dugdale. 2005. Climate anomalies generate an exceptional dinoflagellate bloom in San Francisco Bay. Geophysical Research Letters 32 (14). https://doi.org/10.1029/2005GL023321.

Cloern, J.E., K.A. Hieb, T. Jacobson, B. Sanso, E. Di Lorenzo, M.T. Stacey, J.L. Largier, et al. 2010. Biological communities in San Francisco Bay track large-scale climate forcing over the North Pacific. Geophysical Research Letters 37: L21602. https://doi.org/ 10.1029/2010GL044774.

Cloern, James E., Alan D. Jassby, Tara S. Schraga, Erica Nejad, and Charles Martin. 2017. Ecosystem variability along the estuarine salinity gradient: Examples from long-term study of San Francisco Bay. Limnology and Oceanography 62: S272-S291. https://doi. org/10.1002/lno.10537.

Cole, B.E., and J.E. Cloern. 1987. An empirical model for estimating phytoplankton productivity in estuaries. Marine Ecology-Progress Series 36 (3): 299-305.

Conley, D.J., H.W. Paerl, R.W. Howarth, D.F. Boesch, S.P. Seitzinger, K.E. Havens, C. Lancelot, and G.E. Likens. 2009. Controlling eutrophication: Nitrogen and phosphorus. Science 323 (5917): 1014 1015. https://doi.org/10.1126/science.1167755.

Conomos, T.J., R.E. Smith, D.H. Peterson, S.W. Hager, and L.E. Schemel. 1979. Processes affecting seasonal distributions of water properties in the San Francisco Bay estuarine system. In San Francisco Bay: The urbanized estuary, ed. T.J. Conomos, 115142. San Francisco: Pacific Division of the American Association for the Advancement of Science.

Davis, J.A. 2004. The long-term fate of polychlorinated biphenyls in San Francisco Bay (USA). Environmental Toxicology and Chemistry 23 (10): 2396-2409. https://doi.org/10.1897/03-373.

Deegan, L.A. 1993. Nutrient and energy transport between estuaries and coastal marine ecosystems by fish migration. Canadian Journal of Fisheries and Aquatic Sciences 50 (1): 74-79.

Deegan, L.A., D.S. Johnson, R.S. Warren, B.J. Peterson, J.W. Fleeger, S. Fagherazzi, and W.M. Wollheim. 2012. Coastal eutrophication as a driver of salt marsh loss. Nature 490 (7420): 388-392. https://doi. org/10.1038/nature11533.

Dettmann, E.H. 2001. Effect of water residence time on annual export and denitrification of nitrogen in estuaries: A model analysis. Estuaries 24: $481-490$

Diaz, R.J., and R. Rosenberg. 2008. Spreading dead zones and consequences for marine ecosystems. Science 321 (5891): 926-929.

Duarte, Carlos M., Daniel J. Conley, Jacob Carstensen, and María Sánchez-Camacho. 2009. Return to Neverland: Shifting baselines affect eutrophication restoration targets. Estuaries and Coasts 32 (1): 29-36. https://doi.org/10.1007/s12237-008-9111-2.

Ellison, M.E., and M.T. Brett. 2006. Particulate phosphorus bioavailability as a function of stream flow and land cover. Water Research 40 (6): 1258-1268. https://doi.org/10.1016/j.watres.2006.01.016.

Elmilady, H., M. Wegen, D. Roelvink, and B.E. Jaffe. 2018. Intertidal area disappears under sea level rise: 250 years of morphodynamic modeling in San Pablo Bay, California. Journal of Geophysical Research: Earth Surface. https://doi.org/10.1029/2018jf004857.

Eyre, Bradley D., Damien T. Maher, and Christian Sanders. 2016. The contribution of denitrification and burial to the nitrogen budgets of three geomorphically distinct Australian estuaries: Importance of seagrass habitats. Limnology and Oceanography 61 (3): 11441156. https://doi.org/10.1002/lno.10280.

Ferreira, João G., Jesper H. Andersen, Angel Borja, Suzanne B. Bricker, Jordi Camp, Margarida Cardoso da Silva, Esther Garcés, et al. 2011. Overview of eutrophication indicators to assess environmental status within the European Marine Strategy Framework Directive. Estuarine, Coastal and Shelf Science 93 (2): 117-131. https://doi. org/10.1016/j.ecss.2011.03.014.

Fishman, M. J., and L.C. Friedman. 1989. Methods for Determination of Inorganic Substances in Water and Fluvial Sediment: U.S. 
Geological Survey, Techniques of Water-Resources Investigations, Book 5, Chapter A1. 545p. https://doi.org/10.3133/twri05A1.

Fuller, C.C., A. van Geen, M. Baskaran, and R. Anima. 1999. Sediment chronology in San Francisco Bay, California, defined by ${ }^{210} \mathrm{~Pb}$, ${ }^{234} \mathrm{Th},{ }^{137} \mathrm{Cs}$, and ${ }^{239,240} \mathrm{Pu}$. Marine Chemistry 64: 7-27.

Geider, Richard, and Julie La Roche. 2002. Redfield revisited: Variability of C:N:P in marine microalgae and its biochemical basis. European Journal of Phycology 37 (1): 1-17. https://doi.org/10.1017/ s0967026201003456.

Greening, H., A. Janicki, E.T. Sherwood, R. Pribble, and J.O.R. Johansson. 2014. Ecosystem responses to long-term nutrient management in an urban estuary: Tampa Bay, Florida, USA. Estuarine, Coastal and Shelf Science 151: A1-A16. https://doi.org/10.1016/j. ecss.2014.10.003.

Hager, S.W. 1993. Dissolved nutrient and suspended particulate matter data for the San Francisco Bay Estuary, California, October1988 through September 1991. U.S. Geological Survey Open-File Report 93-57.

Hager, S.W., and L.E. Schemel. 1992. Sources of nitrogen and phosphorus to Northern San Francisco Bay. Estuaries 15 (1): 40-52.

Hauxwell, J., J. Cebrián, and I. Valiela. 2003. Eelgrass Zostera marina loss in temperate estuaries: Relationship to land-derived nitrogen loads and effect of light limitation imposed by algae. Marine Ecology Progress Series 247: 59-73.

Howard, Meredith D.A., Martha Sutula, David A. Caron, Yi Chao, John D. Farrara, Hartmut Frenzel, Burton Jones, George Robertson, Karen McLaughlin, and Ashmita Sengupta. 2014. Anthropogenic nutrient sources rival natural sources on small scales in the coastal waters of the Southern California Bight. Limnology and Oceanography 59 (1): 285-297. https://doi.org/10.4319/lo.2014. 59.1.0285.

Howarth, R.W., A. Sharpley, and D. Walker. 2002. Sources of nutrient pollution to coastal waters in the United States: Implications for achieving coastal water quality goals. Estuaries 25: 656-676.

Hughes, Brent B., John C. Haskins, Kerstin Wasson, and Elizabeth Watson. 2011. Identifying factors that influence expression of eutrophication in a central California estuary. Marine Ecology Progress Series 439: 31-43.

Jaffe, B.E., R.E. Smith, and L.Z. Torresan. 1998. Sedimentation and bathymetric change in San Pablo Bay, 1856-1983. US Geological Survey Open-File Report 98-759. doi: https://doi.org/10.3133/ ofr 98759.

Jassby, A. D., and J. E. Cloern. 2016. wq: Some tools for exploring water quality monitoring data. $\mathrm{R}$ package version 0.4.8. Available at: http://cran.r-project.org/package=wq. Accessed 26 March 2020.

Jassby, A.D., J.E. Cloern, and T.M. Powell. 1993. Organic-carbon sources and sinks in San Francisco Bay - variability induced by river flow. Marine Ecology-Progress Series 95 (1-2): 39-54.

Jeffrey, S.W., R.F.C. Mantoura, and S.W. Wright. 1997. Phytoplankton pigments in oceanography: Guidelines to modern methods. UNESCO Publications. Paris: UNESCO.

Josefson, A.B., and B. Rasmussen. 2000. Nutrient retention by benthic macrofaunal biomass of Danish estuaries: Importance of nutrient load and residence time. Estuarine, Coastal and Shelf Science 50 (2): 205-216. https://doi.org/10.1006/ecss.1999.0562.

Kemp, W.M., W.R. Boynton, J.E. Adolf, D.F. Boesch, W.C. Boicourt, G. Brush, J.C. Cornwell, et al. 2005. Eutrophication of Chesapeake Bay: Historical trends and ecological interactions. Marine Ecology-Progress Series 303: 1-29. https://doi.org/10.3354/ meps303001.

Kemp, W.M., J.M. Testa, D.J. Conley, D. Gilbert, and J.D. Hagy. 2009. Temporal responses of coastal hypoxia to nutrient loading and physical controls. Biogeosciences 6 (2985-3008): 2009.

Kirchman, D.L. 1994. The uptake of inorganic nutrients by heterotrophic bacteria. Microbial Ecology 28: 255-271. https://doi.org/10.1007/ BF00166816.
Lehman, P.W., K. Marr, G.L. Boyer, S. Acuna, and S.J. Teh. 2013. Longterm trends and causal factors associated with Microcystis abundance and toxicity in San Francisco Estuary and implications for climate change impacts. Hydrobiologia 718 (1): 141-158.

Linker, L.C., R.A. Batiuk, G.W. Shenk, and C.F. Cerco. 2013. Development of the Chesapeake Bay watershed total maximum daily load allocation. Journal of the American Water Resources Association 49: 986-1006. https://doi.org/10.1111/jawr.12105.

MacVean, L.J., L.S. Lewis, P. Trowbridge, J.A. Hobbs, and D.B. Senn. 2018. Dissolved oxygen in South San Francisco Bay: Variability, important processes, and implications for understanding fish habitat. Richmond: Technical Report. San Francisco Estuary Institute. Available at https://www.sfei.org/documents/dissolvedoxygen-south-san-francisco-bay-variability-important-processesand-implications. Accessed 26 March 2020.

Martin, M.A., J.P. Fram, and M.T. Stacey. 2007. Seasonal chlorophyll a fluxes between the coastal Pacific Ocean and San Francisco Bay. Marine Ecology Progress Series 357: 51-61.

McCabe, R.M., B.M. Hickey, R. Kudela, K. Lefebvre, N.G. Adams, B. Bill, F. Gulland, R.E. Thomson, W. Cochlan, and V.L. Trainer. 2016. An unprecedented coastwide toxic algal bloom linked to anomalous ocean conditions: The 2015 US west coast toxic algal bloom. Geophysical Research Letters 43 (19): 10366-10376. https://doi. org/10.1002/2016GL070023.

McGlathery, K.J., K. Sundbäck, and I.C. Anderson. 2007. Eutrophication in shallow coastal bays and lagoons: The role of plants in the coastal filter. Marine Ecology Progress Series 348: 1-18.

Monbet, Yves. 1992. Control of phytoplankton biomass in estuaries: A comparative analysis of microtidal and macrotidal estuaries. Estuaries 15: 563-571. https://doi.org/10.2307/1352398.

Moorman, M.C., A.B. Hoos, S.B. Bricker, R.B. Moore, A.M. García, and S.W. Ator. 2014. Nutrient load summaries for major lakes and estuaries of the Eastern United States, 2002: U.S. Geological Survey Data Series 820, 94 p. https://doi.org/10.3133/ds820.

Nixon, S.W. 1995. Coastal marine eutrophication - a definition, social causes, and future concerns. Ophelia 41: 199-219.

Nixon, S.W., and B.A. Buckley. 2002. "A strikingly rich zone" - Nutrient enrichment and secondary production in coastal marine ecosystems. Estuaries 25 (4B): 782-796.

Nixon, S., B. Buckley, S. Granger, and J. Bintz. 2001. Responses of very shallow marine ecosystems to nutrient enrichment. Human and Ecological Risk Assessment 7 (5): 1457-1481.

Novick, E., and D. Senn. 2014. External nutrient loads to San Francisco Bay. Available at: https://sfbaynutrients.sfei.org/sites/default/files/ NutrientLoadsFINAL FINAL Jan232014.pdf San Francisco estuary institute.

O'Dell, J.W. 1993. Method 365.1. Determination of phosphorus by semiautomated colorimetry, ed. Inorganic Chemistry Branch Chemistry Research Division. Cincinnati: USEPA.

O'Shea, M.L., and T.M. Brosnan. 2000. Trends in indicators of eutrophication in Western Long Island sound and the Hudson-Raritan Estuary. Estuaries 23 (6): 877-901. https://doi.org/10.2307/ 1353004

Paerl, H.W., J.L. Pinckney, J.M. Fear, and B.L. Peierls. 1998. Ecosystem responses to internal and watershed organic matter loading: Consequences for hypoxia in the eutrophying Neuse river estuary, North Carolina, USA. Marine Ecology Progress Series 166: 17-25. https://doi.org/10.3354/meps166017.

Paerl, H.W., J.T. Scott, M.J. McCarthy, S.E. Newell, W.S. Gardner, K.E. Havens, D.K. Hoffman, S.W. Wilhelm, and W.A. Wurtsbaugh. 2016. It takes two to tango: When and where dual nutrient (N \& $\mathrm{P})$ reductions are needed to protect lakes and downstream ecosystems. Environmental Science \&Technology 50 (20): 10805-10813. https://doi.org/10.1021/acs.est.6b02575.

Patton, Charles J. , and Jennifer R. Kryskalla. 2003. Methods of analysis by the U.S. Geological Survey National Water Quality Laboratory 
- Evaluation of alkaline persulfate digestion as an alternative to Kjeldahl digestion for determination of total and dissolved nitrogen and phosphorus in water: U.S. Geological Survey, Water-Resources Investigations Report 03-4174.

Peacock, M.B., C.M. Gibble, D.B. Senn, J.E. Cloern, and R.M. Kudela. 2018. Blurred lines: Multiple freshwater and marine algal toxins at the land-sea interface of San Francisco Bay, California. Harmful Algae 73: 138-147. https://doi.org/10.1016/j.hal.2018.02.005.

Rabalais, N.N., R.E. Turner, and W.J. Wiseman. 2002. Gulf of Mexico hypoxia, aka "The dead zone". Annual Review of Ecology and Systematics 33: 235-263. https://doi.org/10.1146/annurev.ecolsys. 33.010802.150513.

Raimonet, Mélanie, and James E. Cloern. 2016. Estuary-ocean connectivity: Fast physics and slow biology. Global Change Biology. https://doi.org/10.1111/gcb.13546.

Sarthou, Géraldine, Klaas R. Timmermans, Stéphane Blain, and Paul Tréguer. 2005. Growth physiology and fate of diatoms in the ocean: A review. Journal of Sea Research 53 (1-2): 25-42. https://doi.org/ 10.1016/j.seares.2004.01.007.

Schoellhamer, David H. 1996. Factors affecting suspended-solids concentrations in South San Francisco Bay, California. Journal of Geophysical Research: Oceans 101: 12087-12095. https://doi.org/ 10.1029/96JC00747.

Schoellhamer, David H. 2011. Sudden clearing of estuarine waters upon crossing the threshold from transport to supply regulation of sediment transport as an erodible sediment pool is depleted: San Francisco Bay, 1999. Estuaries and Coasts 34: 885-899. https:// doi.org/10.1007/s12237-011-9382-x.

Schoellhamer, D.H., M.A. Lionberger, B.E. Jaffe, N.K. Ganju, S.W. Wright, and G.G Schellenbarger. 2005. Bay sediment budget: Sediment accounting 101. In 2005 Pulse of the Estuary: Monitoring and Managing Water Quality in the San Francisco Estuary. Available at https://www.sfei.org/documents/pulseestuary-2005-monitoring-and-managing-water-quality-sanfrancisco-estuary. Richmond, CA: San Francisco Estuary Institute.

Schraga, Tara S., and James E. Cloern. 2017. Water quality measurements in San Francisco Bay by the U.S. Geological Survey, 1969-2015. Scientific Data 4 (1): 4-14. https://doi.org/10.1038/sdata.2017.98.

Schraga, T.S., Nejad, E.S., Martin, C.A., and Cloern, J.E., 2020, USGS measurements of water quality in San Francisco Bay (CA), beginning in 2016 (ver. 3.0, March 2020): U.S. Geological Survey data release, https://doi.org/10.5066/F7D21WGF.
Smith, V.H. 2006. Responses of estuarine and coastal marine phytoplankton to nitrogen and phosphorus enrichment. Limnology and Oceanography 51: 377-384.

Smith, S.V., and J.T. Hollibaugh. 2006. Water, salt, and nutrient exchanges in San Francisco Bay. Limnology and Oceanography 51 (1, part 2): 504-517.

Soetaert, K., and J.J. Middelburg. 2009. Modeling eutrophication and oligotrophication of shallow-water marine systems: The importance of sediments under stratified and well-mixed conditions. Hydrobiologia 629: 239-254.

Solorzano, L. 1969. Determination of ammonia in natural waters by the phenolhypochlorite method. Limnology and Oceanography 14: 799-801.

Stewart, B.M., and P.A.W. Elliott. 1996. Systematic salt effects in the automated determination of nutrients in seawater. Water Research 30 (4): 869-874.

Sutula, M., R. Kudela, J.D. Hagy III, L.W. Harding Jr., D. Senn, J.E. Cloern, S. Bricker, and G.M. Berg. 2017. Novel analyses of longterm data provide a scientific basis for chlorophyll-a thresholds in San Francisco Bay. Estuarine, Coastal and Shelf Science 197: 107118. https://doi.org/10.1016/j.ecss.2017.07.009.

Thebault, J., T.S. Schraga, J.E. Cloern, and E.G. Dunlavey. 2008. Primary production and carrying capacity of former salt ponds after reconnection to San Francisco Bay. Wetlands 28 (3): 841-851.

Wallace, Ryan B., Hannes Baumann, Jason S. Grear, Robert C. Aller, and Christopher J. Gobler. 2014. Coastal ocean acidification: The other eutrophication problem. Estuarine, Coastal and Shelf Science 148: 1-13. https://doi.org/10.1016/j.ecss.2014.05.027.

Walters, R. A., R. T. Cheng, and T. J. Conomos. 1985. Time scales of circulation and mixing processes of San Francisco Bay waters. In Temporal dynamics of an estuary: San Francisco Bay, eds. James E. Cloern, and Frederic H. Nichols, 13-36. Developments in Hydrobiology, vol. 30: Springer Netherlands.

Wells, Mark L., Bengt Karlson, Angela Wulff, Raphael Kudela, Charles Trick, Valentina Asnaghi, Elisa Berdalet, et al. 2019. Future HAB science: Directions and challenges in a changing climate. Harmful Algae 91. https://doi.org/10.1016/j.hal.2019.101632.

Zimmermann, C.F., C.W. Keefe, and J. Bashe. 1997. Determination of carbon and nitrogen in sediments and particulates of estuarine/ coastal waters using elemental analysis, ed. Office of Research and Development National Exposure Research Laboratory. Cincinnati, Ohio 45268: U.S. Environmental Protection Agency. 